Felix Andrist is a senior economist at the Swiss National Bank in Zurich (andrist.felix@snb.ch). Richard G. Anderson is a vice president (anderson @stls.frb.org), and Marcela M. Williams is a senior research associate at the Federal Reserve Bank of St. Louis. This study was completed while Felix Andrist was a visiting scholar at the Federal Reserve Bank of St. Louis. Richard Anderson thanks the Bank of Canada, the Reserve Bank of New Zealand, and the Federal Reserve Bank of Minneapolis for research support during visits there.

\section{Real Output in Switzerland: New Estimates for 1914-47}

\author{
Felix Andrist, Richard G. Anderson, \\ and Marcela M. Williams
}

\section{INTRODUCTION}

n recent years, macroeconomic research has become increasingly concerned with comparisons of the medium- and long-term behaviors of economic activity, that is, with fluctuations in the trend growth rate and volatility of economic activity at business-cycle frequencies. Because relatively long time series of data are essential for such research, this research agenda has stimulated new interest in the measurement of historical levels of economic activity, both in the United States and Europe ${ }^{1}$ In Europe, Switzerland would seem to be a natural candidate for a longer-run comparative analysis. During the 20th century, Switzerland has enjoyed remarkable political and economic stability: For example, no German-style hyperinflation occurred there. More recently, the Swiss National Bank's monetary policy has achieved enviable price stability. The potential for such a study, however, is limited by breaks in the available time series data for Switzerland. Most important, no estimates of Swiss gross domestic product (GDP) during 1914-47 have been published. This study seeks to fill that gap.

\section{MEASURING NATIONAL OUTPUT AND THE VOLATILITY OF BUSINESS CYCLES}

In the United States, shortcomings in the methods used to measure income and output prior to World War II have been central to a debate as to whether the frequency and amplitude of business cycles have been smaller since World War II than during either the pre-war period (before World War I) or the interwar period (1920 to 1939). ${ }^{2}$ Prior to Romer (1986), most macroeconomists seemed to believe that countercyclical macroeconomic policy had damped cyclical fluctuations during the post- war period in the United States, relative to earlier eras. Romer argued that this conclusion was suspect because the measures of gross national product (GNP) on which it rests had been constructed almost entirely from data on the output of industrial and agricultural commodities ${ }^{3}$

Although a set of national income accounts for the United States had been proposed as early as 1840, modern measures of aggregate income and output were not published until 1934, for nominal data, and 1944, for real data. ${ }^{4}$ These measures of GNP for years prior to World War II, Romer argued, overstate the volatility of GNP because cyclical fluctuations in commodity output tend to be larger than fluctuations in other sectors of the economy. She compared the volatility of growth rates of industrial production, commodity output, and GNP during the period between 1920 and 1940, and found that the volatility of the growth rate of industrial production is much higher than that of commodity output, which in turn is higher than that of GNP. She also concluded that including the output of the service sectors reduces spurious volatility because servicesector output has a different cyclical pattern than commodity output.

Building on Romer's analysis, some additional recent studies have concluded that the volatility of U.S. GDP was approximately the same before 1929 as after 1946 (Romer, 1989; Watson, 1994). Others have disagreed, however. While accepting, in principle, the argument that GNP estimates based almost exclusively on commodity output data may display excess volatility, Balke and Gordon (1989) introduce a new method to measure GNP before

\footnotetext{
${ }^{1}$ The concepts and history of the measurement of aggregate economic activity are reviewed in the inserts "An Overview of the Concepts of National Output and Income" and "A Brief History of National Income and Product Accounts."

2 Our use of the terms pre-war, interwar, and postwar follows Romer (1986, 1989, 1999).

${ }^{3}$ Kuznets' estimates of U.S. GNP for the years after 1918 are based on a broad database that includes output of the industrial, agricultural, government, and service sectors. His estimates for the years prior to 1919, however, are obtained largely from commodity output data via multiplication by a scale factor; see Kuznets (1941, 1946), Romer (1989), and Balke and Gordon (1989).

${ }^{4}$ See the insert "The Development of U.S. National Income Accounting" and Bureau of Economic Analysis (2000).
} 


\section{AN OVERVIEW OF THE CONCEPTS OF NATIONAL OUTPUT AND INCOME}

In the arithmetic of national income accounting, gross domestic product at market prices, or GDP, is a measure of the total production that occurs within a country. GDP is measured by summing:

(1) The market value of the goods and services purchased by the consumers, firms, and governments within the country, plus the value of exported goods and services; and,

(2) The value of intermediate products purchased for inventory by firms, including partially completed products for further processing.

From this total, two items are subtracted:

(3) All goods and services, purchased by firms, which were fully used up in the production of goods and services; and,

\section{(4) All imported goods and services.}

In some cases, the market prices that are charged by government-sponsored enterprises for goods and services differ from the prices that would be charged by private-sector firms; if so, the size of GDP is adjusted for the difference.

National income accounting discussions often also define the concept of gross national product, or GNP. ${ }^{1}$ GNP equals the sum of GDP plus the net factor income received by domestic residents from nonresidents. ${ }^{2}$ For Switzerland, as for other countries, such factor income includes two components: payments received by Swiss residents from nonresidents for the use of Swiss-owned capital abroad, minus payments by Swiss residents to nonresidents for the use in Switzerland of foreign-owned produc- tion capital; and, labor compensation received by residents from abroad (including the employees of international organizations and foreign embassies in Switzerland), minus the compensation of border workers. ${ }^{3}$

Both GDP and GNP have net counterparts: net domestic product, NDP, and net national product, NNP. These net concepts are equal to their gross counterparts minus the estimated physical wearing out, or depreciation, of capital. Note that deprecia tion in the national income accounts may differ substantially from the so-called accelerated depreciation permitted by various government tax codes. In the national accounts, depreciation is based on best-effort estimates of the rate at which capital physically deteriorates.

The goods and services included in both GDP and GNP are valued at market prices, including taxes. Tax revenue accrues to the government, however, and not to households and firms. The concept of net national income, NNI, is equal to NNP minus indirect (excise and sales) taxes and a small number of similar adjustments. As such, it measures the income of households and firms due to producing goods and services.

\footnotetext{
${ }^{1}$ The United Nations system of national income accounts does not include the production-side measure of GNP as defined in the text. Rather, it includes an income-side measure, labeled gross national income, or GNI. GNI is measured by summing the factor incomes of the same households, firms, and governments that are included in GDP. With allowance for indirect (excise) taxes and statistical discrepancies, the GNI and GNP measures are the same. See System of National Accounts 1993, p. 163.

2 Factor income is income generated by the production of goods and services. The compensation of workers (wages and salaries) is labor factor income; payments received for the use of equipment, structures, or land are capital factor income. The United Nations system of national income accounts refers to factor income as primary income (System of National Accounts 1993, chapter 7).

${ }^{3}$ Border workers are residents of one nation who work routinely in another. For discussion, see the International Monetary Fund's Balance of Payments Manual (1993).
}

1919. Their method, which combines available fragmentary data on components of GNP with related data on indicators of the state of the economy, supports the hypothesis that volatility before 1929 was higher than after 1946. These controversies regarding historical GNP measurement and volatility are surveyed in the Journal of Economic Perspectives, Spring 1999, especially Romer (1999).
Looking beyond the United States, other analysts have compared pre- and post-World War II data for European countries. Some of these nations established statistical agencies well before the United States, and hence, longer time series of data are available Sheffrin (1988), for example, examined data for GDP, GNP, and industrial production in six countries: the United Kingdom, Denmark, Sweden, Italy, Norway, and 


\section{A BRIEF HISTORY OF NATIONAL INCOME AND PRODUCT ACCOUNTS}

Like much of recorded history, the measurement of national income began much earlier in Europe than in the United States. In the Middle East, as early as $3000 \mathrm{BC}$, the Babylonians developed a simple aggregate balance sheet of the State ${ }^{1}$ Somewhat later, the Greeks and Romans created a simple system of national economic accounts to calculate their national government budgets.

William Petty's (1623-87) “Political arithmetick," written in England in 1676 (but not published until 1690), often is cited as the beginning of modern economic statistics. ${ }^{2}$ Petty calculated balance sheets for various economic groups and then aggregated the information into a measure of national income Behind his analysis lay both a general movement in science away from qualitative description toward quantitative measurement, and a need for the government to increase tax revenues to fight wars both within and outside England. Of his own analyses, Petty wrote that he was seeking to identify for economic events, "such causes, as have visible foundations in nature" 3 Later, during 1696 in England, Gregory King (1648-1712) published a greatly expanded measure, and suggested methods to forecast national income ${ }^{4}$

The French Physiocrats followed Petty, at least chronologically. Perhaps the most prominent among these is Quesnay (1694-1774). The influence of his work on the writings of Adam Smith (1723-90) seems clear. During his early years, at various times, Smith was a professor of literature, logic, and moral philosophy. ${ }^{5}$ In his early forties, Smith becamea tutor to the son of a French duke and, during his sojourn in France, was exposed to the writings of the Physiocrats, including Quesnay. Being thereafter able to retire at a young age, Smith wrote the Wealth of Nations. Smith lauds Quesnay's system in Book IV, chapter IX, p. 642: “This [physiocratic] system, however, with all its imperfection, is, perhaps, the nearest approximation to the truth that has yet been published upon the subject of political economy."
The modern value of the writings of the Physiocrats long has been debated. In his Tableau Economique (1758), Quesnay distinguished a variety of economic sectors and presented his analysis in "economic tables." Some analysts have suggested that this work may be interpreted as an eighteenthcentury, bare-bones, general-equilibrium model of the economy. ${ }^{6}$ Beyond Quesnay, Laurent Lavoisier (1743-94), the founder of modern chemistry, developed an account system that extended Quesnay's definition of a nation's wealth to include other sectors in addition to agriculture. Lavoisier and other Physiocrats also addressed questions regarding the formation and distribution of wealth, using an analysis of the flows of goods and income among sectors in their models.

During the period of liberalism in Europe-the 19th and the first two decades of the 20th centurythe theory of business cycles lost its importance Markets were seen as self-regulating and, hence, national income accounting as unimportant. In the thinking of Say (1767-1832), who was one of the most important liberal economists, the concept of national income and its accounts was purely a bureaucratic tool to allow intervention or meddling in the economy. Economists' attention turned to finding leading indicators that forecast more precisely.

The period between World I and World War II saw a resurgence of interest in national income measurement. Notable work includes that of Wyler (1927) and other Swiss writers during the 1920s, Kuznets in the United States during the 1930s, andperhaps most closely related to Quesnay's tables-

\footnotetext{
${ }^{1}$ Lurati (1993)

${ }^{2}$ Studenski (1958) provides a detailed analysis of the work of Petty and his contemporaries, as well as an overview of national income estimates for many other countries.

${ }^{3}$ This quotation of Petty is from Roncaglia (1987).

${ }^{4}$ King's work is described by Studenski (1958).

${ }^{5}$ Samuelson (1976)

${ }^{6}$ Samuelson (1982)
}

continued on next page
France Except for France, measures of GDP or GNP are available at least as early as 1871, although details regarding the measurement of GDP in Norway are not available For the United Kingdom, Italy, and France, industrial production data are available as early as 1871. Sheffrin separates the data into three intervals1871 to 1913,1922 to 1938 , and 1951 to 1983 -and concludes that, except for Sweden, there is little 
continued from previous page

Leontief's research on input-output relationships. Mobilization for World War II accelerated national income research in the United Kingdom and led to the publication of the important study by James Meade and Richard Stone, "National Income and Expenditure," in 1944. ${ }^{7}$ Later, Stone was instrumental in developing the United Nations national income accounting system, which was introduced in 1952 and subsequently revised several times. In its 1984 award of the Nobel prize in economics to Stone, the Royal Swedish Academy chose not to divide the award among researchers, but rather to stress the importance of Stone's work in developing the national income accounts. $^{8}$ The most recent version of the United Nations system, System of National Accounts 1993, has been adopted by most nations and by international organizations including the World Bank, IMF and Eurostat.

\footnotetext{
${ }^{7}$ The first edition of Meade and Stone was published in London during 1944; the fourth, and final, edition was published in 1957. This work later was superceded by the publication of Stone and Stone (1961) under the same title.

${ }^{8}$ Samuelson (1985).
}

evidence of any change in volatility between the prewar period, 1871 to 1913, and the post-war period, 1951 to 1983. The data for Sweden suggest that volatility was damped somewhat by stabilization policy.

\section{MEASURING SWISS NATIONAL INCOME AND OUTPUT}

Data scarcity has plagued all attempts to measure Swiss aggregate production and income. As a result, early estimates were produced by a variety of authors for a number of separate, individual years. Some such estimates were measures of the economy's income, others were measures of its output. ${ }^{5}$ Geering and Hotz $(1902,1910,1914)$ published estimates of net national income for 1890, 1895, 1899, 1906, and 1913 , and "total production" for 1890, 1895, 1899, and 1906. Landmann (1916) produced an estimate of net national income for 1913, the Swiss Federal Tax Office (1920) published estimates of net national income for 1915, and Schneider (1921) published an estimate for $1919 .{ }^{6}$ Julius Wyler (1927 and 1928) published a measure of output for 1924 that Studenski (1958, p. 467) called “... the most comprehensive estimate [of net national product at market prices] ever prepared for that country." Mori (1928) also published an estimate of NNP at market prices for 1924 based on income data. Wyler's estimate of 8,000 million Swiss francs was more than 20 percent larger than Mori's estimate of 6,600 million Swiss francs, a difference that in large part reflects Wyler's much higher estimates of salary and capital income. In several subsequent articles, Wyler and Mori discussed the quality of their estimates (see Zeitschrift für Statistik und Volkswirtschaft, 1927 and 1928). At the conclusion of the debate, Wyler's methods were adopted for most national income and net national product estimations. Subsequently, at the Federal Statistical Office, Wyler published estimates of aggregate national income (net national product, or NNP, and net national income, or NNI) for 1929-38 (Federal Statistical Office of Switzerland and Wyler, 1941). Later, using the framework of the 1958 OECD Manual of National Accounts, Zwingli and Ducret (1964) produced an estimate of the economy's output, net national product at market prices, for $1910{ }^{7}$ Below, these scattered estimates provide benchmarks for our time-series estimates of annual GDP. The historical data are published in Historical Statistics of Switzerland (1996). The sources of the data used in this study are summarized in the appendix to this article

In more recent years, measures of aggregate output and income have been produced by the Swiss Federal Bureau of Statistics. In 1941, the Bureau began to publish annual estimates of output (net national product) based on Wyler's method; these continued until 1960. In 1947 and 1948, the Bureau adopted new estimation methods as proposed by the United Nations (later to become the United Nations

\footnotetext{
${ }^{5}$ Most estimates of aggregate economic activity in Switzerland have been calculated from the "income side" of the economy, for example, as net national income rather than net national product. Estimates directly based on production, rather than income, only are published for the years 1965, 1975, 1985, and 1991-96.

${ }^{6}$ See Statistisches Jahrbuch der Schweiz 1993.

${ }^{7}$ Two additional estimates for net national product during 1910 are mentioned in Historical Statistics of Switzerland (1996, p. 863). Both are based on smaller datasets than Zwingli and Ducret (1964). We do not use either in our analysis.
} 


\section{THE DEVELOPMENT OF U.S. NATIONAL INCOME ACCOUNTING}

Although economists have estimated the national income of the United States for more than a century and a half, the regular publication of data on aggregate economic activity is a relatively recent phenomenon. The earliest estimates of national income were prepared by George Tucker (17751861), for the year $1840 .{ }^{1}$ Later, Charles Spahr published estimates for 1890, and Willford King produced estimates for $1910 .^{2}$ During the 1920s, the National Bureau of Economic Research published a number of studies of national income by Wesley Mitchell, Willford King, and others. Yet, the first modern estimates of nominal aggregate production, or gross national product, were published only in March 1942. Constant-dollar (real) GNP measures were first published for annual data during 1951, and for quarterly data in 1958.

Prior to the 1930s, analyses of economic activity most often were based on the examination of individual data series such as the number of railcar loadings and the production of pig iron. The inaugural issue of the Survey of Current Business, for example, dated July 1, 1921, contained approximately 500 such series; by 1931, the Survey contained approximately 2000 series (Teper, 1971). The inadequacy of this plethora of individual-series data for macroeconomic analysis became apparent to many analysts during the Great Contraction of 1929-32. As a result, in 1932 the U.S. Senate adopted Resolution 220 which called for the Department of Commerce to develop measures of the level of aggregate national income $^{3}$ Under the direction of Simon Kuznets, the project proceeded during 1933 in cooperation with the National Bureau of Economic Research. The first such measures of national income were published in the February 1934 issue of the Survey of Current Business.

Although the Department of Commerce and NBER expanded their efforts in national income accounting during the 1930s, the work largely was confined to the income side of the economy and sought to provide better measures of items such as wages and profits. Efforts to measure total production were stimulated by the onset of World War II to support wartime mobilization. This American experience -in which national income accounting benefited greatly from major events such as the Great Depression and World War II-is not unprecedented. Jaszi (1971) notes that the development of national income accounting in England during the seventeenth century benefited from two fiscal crises, one that occurred during the early part of the century and another at the time of the Industrial Revolution.

In early 1996, the Department of Commerce introduced index-number methods to measure GDP. ${ }^{4}$ In such methods, annual and quarterly changes are calculated using a formula that includes weights from adjacent years. For example, the 1997-98 annual percentage change in real GDP is measured using the levels of prices during 1997 and 1998 as weights, and the 1997-98 annual percentage change in the "price" of real GDP is measured using the quantities of output during 1996 and 1997 as weights.

In actual practice, data on the aggregate physical output of various products in the economy is not available to measure GDP. Rather, Federal government surveys provide data on the total current-dollar sales of goods and services; the "real" quantities of these goods and services are cal culated by deflating the sales data by appropriate price indexes at the most detailed level possible.

\footnotetext{
${ }^{1}$ Tucker, George. Progress of the United States in Population and Wealth in Fifty Years, New York, 1843 (cited by Studenski, 1958, p. 525). Tucker's estimates for 1840 and later, for 1850, are discussed by Studenski (1958), p. 129-132

${ }^{2}$ Charles B. Spahr, An Essay on the Present Distribution of Wealth in the United States, New York, 1896. Willford I. King, The Wealth and Income of the People of the United States, New York, 1915. Both cited by Studenski, p. 525-27. Other important early estimates are Willford I. King, The National Income and Its Purchasing Power, 1930, National Bureau of Economic Research, and Simon Kuznets, National Income and Capital Formation, 1937, National Bureau of Economic Research.

${ }^{3}$ See Ruggles and Ruggles (1971), Jaszi (1971), and Teper (1971).

${ }^{4}$ Bureau of Economic Analysis (1996).
}

System of National Income Accounts, developed in large part by Richard Stone). ${ }^{8}$ Although some measures of national economic activity subsequently

\footnotetext{
${ }^{8}$ The most recent version is the System of National Accounts 1993, which is jointly published by Eurostat, the International Monetary Fund, the Organisation for Economic Co-operation and Development, the World Bank, and the UN.
} 
were revised as far back as 1938 (for example, national income at market prices, and personal income before and after taxes), no aggregate production or national expenditure data were produced. A number of attempts were made by the Federal Bureau during the 1950s and 1960s to fill this gap (see Historical Statistics of Switzerland, 1996, chapter Q, pp. 880-81); largely due to inadequate data, these were unsuccessful. The nature of the problems were summarized in a 1952 report of the National Accounts Research Unit of the Organization for European Economic Co-operation (quoted by Studenski, 1958, p. 467):

- "certain basic information on the economic activity of the country is only partially recorded or not available at all...no census of Industrial Production has ever been taken ... and only very few current production series are available" ... "No balance of payments statistics are published."

- "the collection of data required for setting up the national accounts is in some ways complicated by the [federal] political structure of Switzerland."

- "there appears to be a markedly cautious attitude among Swiss official statisticians ... which leads to a reluctance to publish official figures based predominantly on estimates or mere assumptions."

- "government economic planning plays a less important rolethan in many European countries."

These problems notwithstanding, in 1977 the Federal Bureau replaced its earlier estimates with new, more complete measures. Retrospective estimates of annual GNP were published as far back as 1948. The contemporaneous publication of quarterly GDP began in 1981; retrospective measures of quarterly GDP as far back as 1965 were published in 1983.

Measuring Swiss economic activity prior to 1948 has been more difficult. Comprehensive annual measures of GNP for 1851-1913 were produced during the late 1980s by a Swiss National Fund project, "Money Supply and Economic Growth in Switzerland 1851-1913." Their methods are discussed at length in Historical Statistics of Switzerland (1996), chapter Q, pp. 880-84. To estimate GDP, the project collected an extensive set of basic historical data, including the value added in commodity production and the outputs of various service sectors such as tourism, transportation, banking, insurance, the public sector (government), personal services, and commerce (retail and wholesale trade). Many of the data were collected from primary sources, including surveys of, and visits to, individual plants and firms. Unfortunately, due to scarcities of both data and funding, the project did not develop measures of national income after 1913.

Here, we seek to fill the gap between the National Fund project's estimate for 1913 and the Federal Bureau's estimate for 1948. In the next section, we examine the available aggregate data for Switzerland and propose a method to measure GDP for each year from 1914 to 1947. In the terminology introduced by Balke and Gordon (1989), our method is indicator, rather than component, based. That is, our estimator utilizes data that are not included directly in measuring aggregate output but likely display similar time-series behavior. We ask the reader to bear in mind that for no period prior to 1948 are the commodity output data available for Switzerland comparable in coverage or quality to those used by Simon Kuznets (1941) to estimate income and output for the United States; hence, by necessity, our indicator-based method is cruder than Kuznets' component methods.

\section{AVAILABLE SWISS MACROECONOMIC INDICATORS FOR GDP}

Only a small number of indicators of Swiss aggregate economic activity from 1914 to 1947 are available

- The transport volume of Swiss railroads (on an annual basis since 1882) is available in Historical Statistics of Switzerland. This is the only consistently available measure of the level of economic activity for this period. Lacking other information, staff of the Swiss National Bank have used these data as an indicator of economic growth between the years 1907 and 1929 (Ruoss, 1992).

- An annual index of industrial production, due to David (1995), is available for the period between 1913 and 1945.

- Data on the annual number of guest arrivals at Swiss hotels are available for the years 


\section{Table 1}

\section{Selected Published Measures of Swiss Aggregate Economic Activity, 1900-48}

(Millions of Swiss Francs)

Concept

Net National Income

Total Production:

Net National Product
Author and Date Published

Geering and Hotz $(1902,1910,1914)$

Zwingli and Ducret (1964)

Landmann (1916)

Mori (1928)

Swiss Federal Tax Office (1920)

Schneider (1921)

Wyler (1927 and 1928)

Federal Statistical Office of Switzerland (1941)
As-of Date and Amount

1906: 2,000

1913: $2,500-3,000$

1910: 4,222

1913: 3,500

1913: 3,419

1915: 4,378

1919: 6,686

1924: 7,738

1929: 9,469

1930: 9,344

1931: 8,609

1932: 7,685

1933: 7,698

1934: 7,599

1935: 7,429

1936: 7,457

1937: 8,160

1938: 8,202

1906: 3,100

1910: 4,324

1924: 6,600

1924: 8,000

1929: 9,753

1930: 9,634

1931: 8,905

1932: 7,987

1933: 8,006

1934: 7,913

1935: 7,749

1936: 7,783

1937: 8,492

1938: 8,542

1938: 9,046

1939: 9,225

Federal Statistical Office of Switzerland (1943 and following years) 
Table 1 continued

\begin{tabular}{|c|c|c|c|}
\hline \multirow[t]{2}{*}{ Concept } & \multirow[t]{2}{*}{ Author and Date Published } & \multicolumn{2}{|c|}{ As-of Date and Amount } \\
\hline & & 1940: & 9,678 \\
\hline \multirow[t]{15}{*}{ GDP } & \multirow{14}{*}{$\begin{array}{l}\text { Swiss National Fund project, } \\
\text { in Historical Statistics of Switzerland (1996) }\end{array}$} & 1900: & 2,507 \\
\hline & & 1901: & 2,484 \\
\hline & & 1902: & 2,559 \\
\hline & & 1903: & 2,531 \\
\hline & & 1904: & 2,685 \\
\hline & & 1905: & 2,783 \\
\hline & & 1906: & 3,143 \\
\hline & & 1907: & 3,338 \\
\hline & & 1908: & 3,354 \\
\hline & & 1909: & 3,536 \\
\hline & & 1910: & 3,739 \\
\hline & & 1911: & 3,965 \\
\hline & & 1912: & 4,117 \\
\hline & & 1913: & 4,009 \\
\hline & Swiss Federal Bureau of Statistics (1998) & 1948: & $\begin{array}{l}19,899 \text { (at Market prices) } \\
89,000 \text { (1990 prices) }\end{array}$ \\
\hline
\end{tabular}

between 1914 and 1948 in Historical Statistics of Switzerland (1996). The usefulness of these data as a measure of the output of the tourism sector is limited, however, because data on the average duration of guests' stays are not available for the years between 1914 and 1920. The average number of nights that a typical tourist stayed in a hotel is known to have been significantly higher before World War I than it was after the war. For that reason, increases in the number of arrivals may not be a good measure of tourism as a whole. The size of the bias is suggested by comparing the average annual growth rate of the two indicators between 1920 and 1930: The number of arrivals increased at an average rate of 4 percent, but the number of nights increased at only a 2-percent rate

- Measures of net national income and net national product have been produced for various years (see Table 1). ${ }^{9}$ Nominal NNI estimates, based on income and fiscal (tax collection) data, have been published for the years 1910, 1915, 1919, 1924, and annually for the years between 1929 and 1938. Measures of nominal NNP for 1910, 1924, and annually for 1929-48, based on income and production data, are published in Historical Statistics of Switzerland (1996). ${ }^{10}$

- The only measure of the price level available between 1914 and 1948 is the Swiss consumer price index (in Historical Statistics of Switzerland). An annual Swiss cost-of-living index is available beginning in 1938.

Discrepancies almost are inevitable in such varied and overlapping data. For example, the estimates by Wyler and Mori of NNP during 1924 differ by more than 25 percent (see Table 1). As a

\footnotetext{
${ }^{9} \mathrm{NNI}$ differs from NNP (at market prices) by the amount of indirect (excise and sales) taxes included in market prices and by a statistical discrepancy, or subvention. NNI is measured as the primary income (income due to the production of goods and services) received by households and firms. NNP is measured as the market value of these goods and services. (The most recent United Nations and European Union system of national income accounts does not include the concept of NNP; see System of National Accounts 1993.) The relationships among national income and output concepts are discussed further in the insert, "An Overview of the Concepts of National Output and Income."

${ }^{10}$ See also Statistisches Jahrbuch der Schweiz 1993 (Statistical Yearbook of Switzerland, 1993).
} 


\section{Figure 1}

\section{Share of Depreciation in GDP}

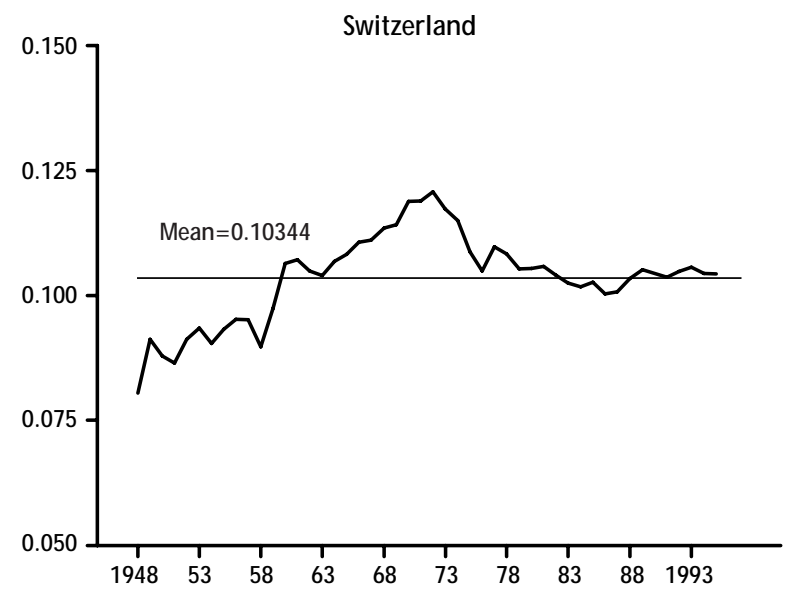

GDP Growth vs. Share of Depreciation in GDP, Switzerland

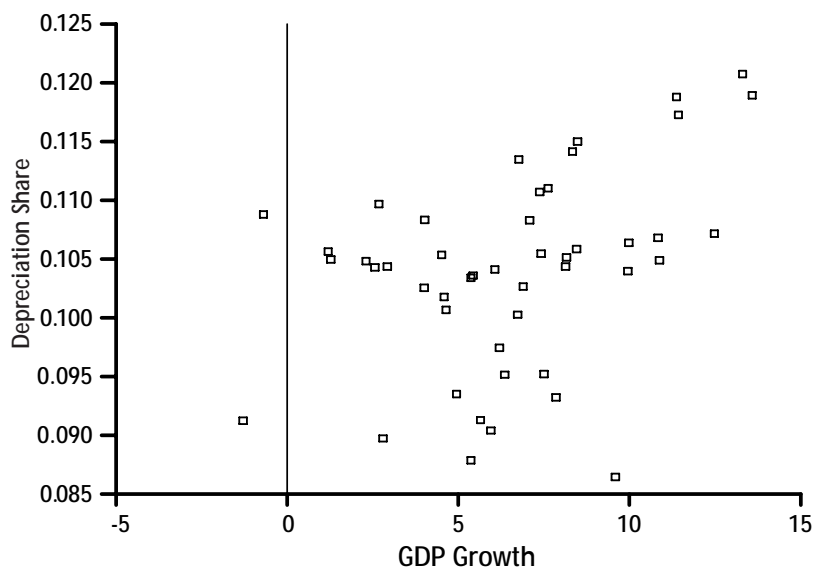

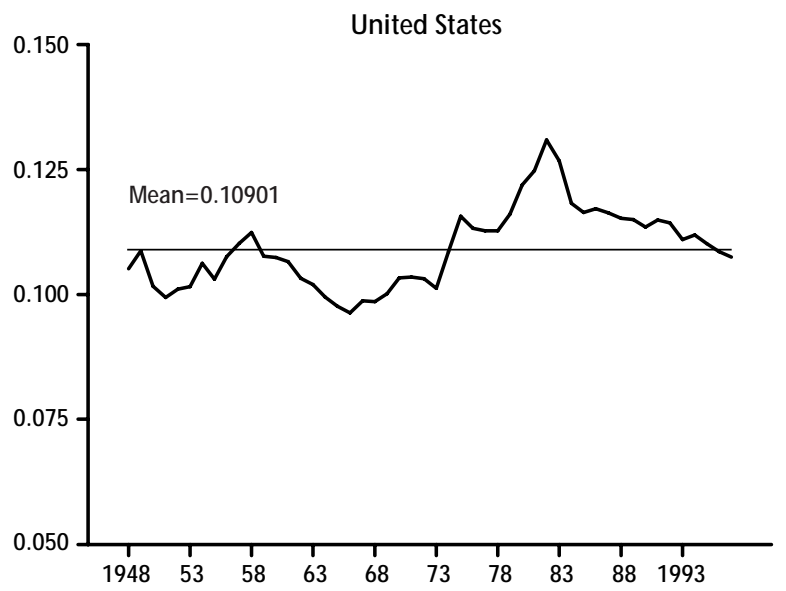

GDP Growth vs. Share of Depreciation in GDP, United States

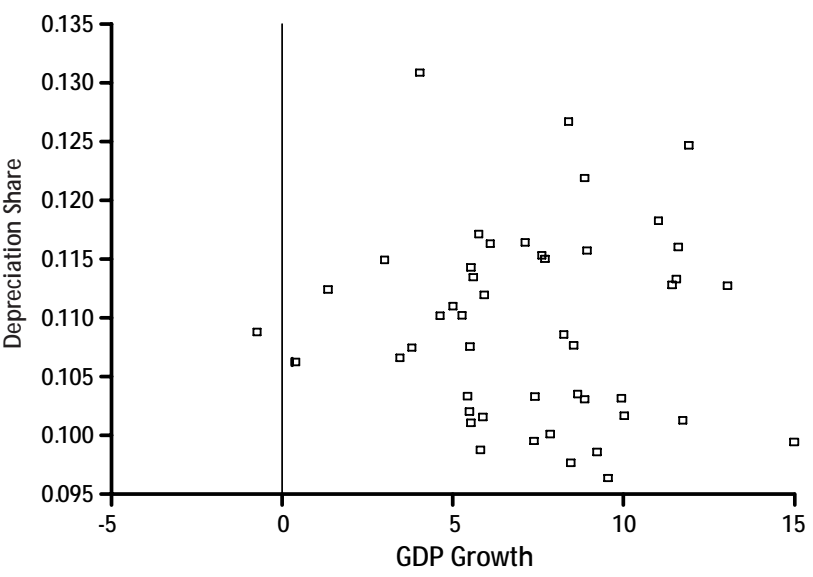

second example, the Swiss National Fund project's estimate of GDP during 1910, which includes depreciation, is less than Zwingli and Ducret's (1964) estimate of NNP, which excludes depreciation.

Because early researchers appreciated the role of foreign capital income in Switzerland, such data are more available and of better quality. Landmann (1916) estimated that net Swiss factor income derived from capital investment abroad during 1910 was 100 to 150 million Swiss francs. This estimate is based on income received by Swiss residents from their holdings of bonds issued abroad (denominated in foreign currencies) and excludes labor income. An alternative estimate of $\mathbf{3 0 0}$ million Swiss francs, including both income from capital exports and foreign investment, was published during 1925 in the annual report "Handels-und Zahlungsbilanz" (Balance of Trade and Payment). Immediately after World War I, income from capital exports fell almost to zero. For the year 1924, the author(s) of the same report estimated Swiss net foreign income at 150 million Swiss francs, approximately the level of 1910. Later, both Wyler (1927) and Zwingli and Ducret (1964) included foreign income in their estimates of net national product.

Unlike net foreign income, we have been unable to locate any estimates of depreciation between 1913 and 1948. In our analysis, we assume that the share 
Figure 2

\section{Swiss Industrial Production, Railroad Volume and Tourism}

Annual Data, 1913-31
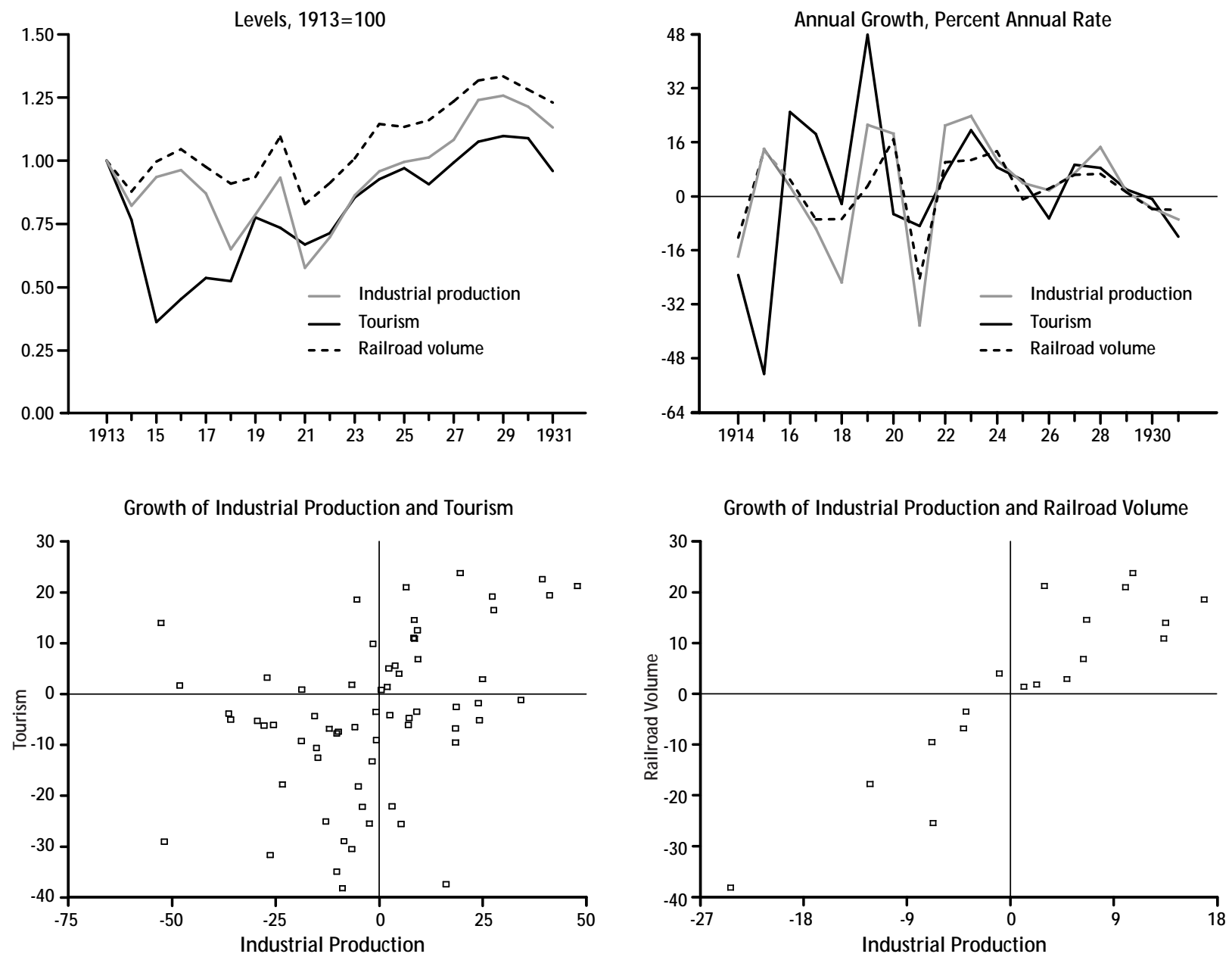

of depreciation in GDP is constant at 10.3 percent, its mean between 1948 and 1995. Annual data on the share of depreciation in Swiss GDP between 1948 and 1995 is shown in Figure 1; for comparison, the share in U.S. GDP also is shown. ${ }^{11}$ In Switzerland, the share increases until the recession of the mid1970s, when it levels off at approximately its post-World War II mean. ${ }^{12}$ (From 1948 to 1995 , economic growth in Switzerland was characterized by a small recession during 1959 and by a sharper one during the mid-1970s.) In the United States, the share is more volatile, although the mean is similar. The scatter plots shown in the lower panels of the figure confirm that there essentially is no correlation between the share of depreciation in GDP and the growth rate of GDP, which suggests that our assumption of a constant share may be satisfactory.

Our estimate of depreciation between 1914

\footnotetext{
${ }^{11}$ The Swiss data are from the Federal Bureau of Statistics and are based on the 1968 United Nations national income accounts framework. All data reflect GDP and its components valued at market prices. Although the Federal Bureau has published national accounts data based on newer methodology (including revised estimates for the years between 1980 and 1995 based on the 1975 methodology of the European Community) these newer estimates have not been chained to earlier data.

${ }^{12}$ For the years between 1948 and 1995, the median share is 0.1048 , and the standard deviation is 0.0089 .
} 
and 1948 is imprecise, at best. Previously published Swiss historical data, however, also reveal a great deal of uncertainty regarding depreciation. Recall that the Swiss National Fund project's estimate of GDP during 1910, published in Historical Statistics of Switzerland (1996), is approximately 600 million Swiss francs below the estimate of NNP published by Zwingli and Ducret (1964).

Despite its imprecision, our depreciation assumption suggests reasonable longer-run relationships between GDP and NNP. Consider a comparison of 1910 and 1924. If the share of depreciation in the National Fund project's estimate of GDP during 1910 was 10 percent, depreciation would have been approximately 370 million Swiss francs. ${ }^{13}$ If depreciation subsequently increased at an average annual rate of 4.5 percent between 1910 and 1924, depreciation during 1924 would have been approximately 680 million Swiss francs, equal to 8.6 percent of Wyler's (1927) estimate of 1924's GDP and 10.4 percent of Mori's (1928) estimate ${ }^{14}$ Both are within the range of depreciation shares observed in post-World War II Swiss data. Nonetheless, the annual growth rates of Swiss GDP and NNP between 1948 and 1995 hardly differ. In this period, the NNP growth is a valuable indicator of GDP growth. We also assume that this relation between the two annual growth rates holds between 1930 and 1948 and that the annual growth rates of GDP are the same as those of NNP.

\section{AN ESTIMATOR FOR ANNUAL SWSS GDP}

We propose that a reasonable time series of estimates for Swiss annual GDP should satisfy these conditions:

A. Its average annual growth rate should be the same as the trend suggested by other measures of aggregate economic activity, including previously published estimates of GDP for individual years.

B. Its business-cycle behavior should be the same as that of other annual macroeconomic indicators.

C. Its volatility at frequencies shorter than those of business cycles should be the same as other annual macroeconomic indicators.

Although we regard violations of A to be more serious than violations of $B$, and violations of $B$ to be more serious than violations of $C$, an acceptable estimator should do a reasonably good job of satisfying all three conditions. Balke and Gordon (1989) emphasize two important steps to measure GDP via indicator variables-estimate the long-run trend and estimate deviations around that trend. In our analysis, the long-run trend is determined by the published values of GDP at the endpoints of our estimation interval, 1913 and 1948. Note that the published data for 1913 are nominal GDP, while our estimation procedure is concerned with real GDP. For 1948, measures of both nominal and real GDP have been published by the Swiss Federal Bureau of Statistics. In our comparisons, we deflate the published nominal levels by the Swiss CPI.

\section{4- 29}

We first seek to measure real GDP growth between 1914 and 1929. Indicator variables available include the number of guests arriving at Swiss hotels, TO, available annually between 1910 and 1948; the transportation volume of Swiss railroads, TR, published annually beginning 1880; the index of annual Swiss industrial production, IP, between 1913 and 1945, due to David (1995); and, beginning 1929, annual nominal net national product and net national income ${ }^{15}$ Data for TO, TR, and IP are displayed in Figure2. Summary statistics, based on these annual data and previously published data for NNP and NNI during individual years, are shown in Table 2 for four intervals: 1910-24, 1915-24, 1924-29, and 1915-30. Data sources are listed in the appendix.

Figure 2 suggests that the behaviors of the three indicators TO, TR, and IP are broadly similar. Railroad transport, TR, and industrial production, IP, both display growth rates similar to those of deflated NNP and NNI (Table 2), and the growth rates of TR and IP are positively correlated (lower-right panel, Figure 2). During the earlier periods that are dominated by

\footnotetext{
${ }^{13}$ This is based on the Swiss National Fund's GDP estimate for 1910 of 3.739 billion Swiss francs. Zwingli and Ducret (1964) estimate that NNP was about 4.324 billion francs, but provide no estimate of GNP or GDP.

${ }^{14}$ The Swiss National Fund project (1996) estimated 1913's GDP at 4.009 billion Swiss francs; the Swiss Federal Bureau of Statistics estimates that $1948 \mathrm{GDP}$ was 19.899 billion francs. The implied average annual growth rate is 4.5 percent.

${ }^{15}$ During these time periods, the difference between NNI and NNP_-primarily sales and excise taxes-likely is small. We obtain real NNP and NNI by dividing published nominal NNP and NNI by the published CPI.
} 


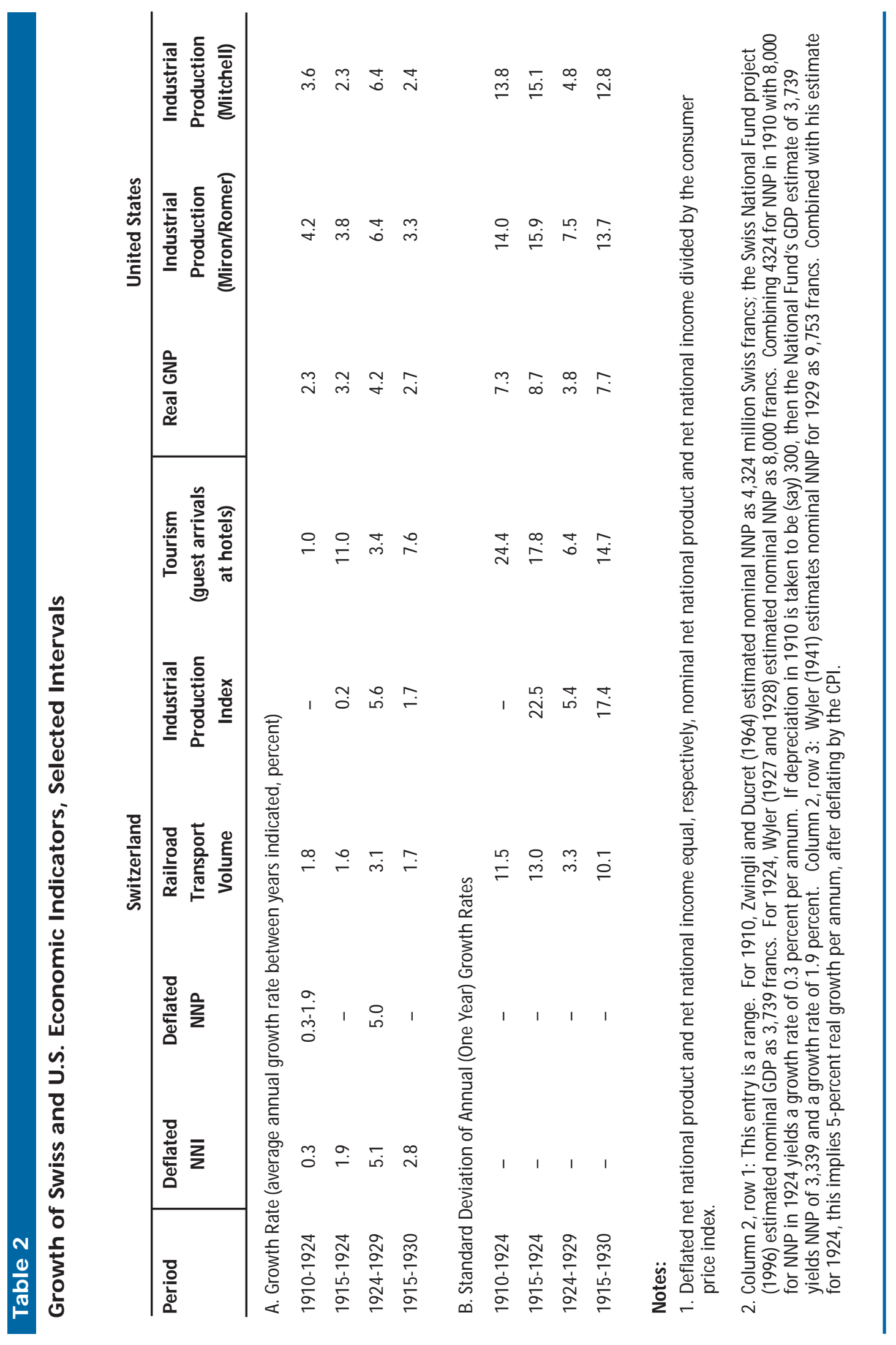


years before 1925-1910 to 1924, 1915 to 1924 , and 1915 to 1930-TR growth is closer to the growth of NNP and NNI. During the later period 1924-29, however, IP growth is closer to the growth of NNP and NNI. Other differences also are apparent. Duringall four periods in Table 2, tourism's average annual growth rate is much larger than the growth rates of TR and IP. Fluctuations in the annual growth rate of TO are not correlated closely with those of IP (lowerleft panel, Figure 2). At the onset of World War I in Europe, tourism's growth rate decreases rapidly; in 1915, it reverses path and begins to increase rapidly (see Figure 2).

Romer (1999 and earlier references therein) finds that indicators of service-sector and commoditysector output in the United States differ with respect to volatility and cyclical patterns. As a result, she concludes that measures of U.S. GDP will display spurious volatility if based primarily on commoditysector output. Our data suggest that this is not true for Switzerland. After World War I, the service-sector measures, TO and TR, display approximately the same volatility and cyclical behavior as industrial production. Why in Switzerland do fluctuations in service-sector and commodity-sector output more closely resemble each other than in the United States? Likely because Switzerland is a small open economy, and fluctuations in economic activity in most sectors are strongly correlated with foreign demand. Decreases in IP during periods such as 1915-18, 1921, and 1930-35, for example, reflect larger decreases in foreign than domestic demand. ${ }^{16}$ This common cyclical pattern, however, does not suggest that there is no risk of spurious volatility. During 1948-95, the volatility of both industrial and service-sector output is higher than that of GDP. This suggests that-to avoid the problem of excess volatility-an indicator-based estimator of GDP might attempt to exploit the apparent negative covariance between indicators of commodity-sector and servicesector output. We do not do so in this study, however, believing that this would be asking too much of the available fragile Swiss historical data.

Because it seems likely that a measure of real GDP between 1914 and 1929 that is based directly on TR or IP would display spurious volatility, we measure the annual growth rates of real GDP as centered three-period moving averages of these indicators' growth rates. Let us denote the (log) level of a data series by $z_{t}$ and define the lag operator $\mathrm{B}^{\mathrm{j}}$ as $B^{j}=z_{t-i}$. Then a centered three-period moving average filter, denoted as $M A(3) z_{t}$, is defined by the equation

$$
=(1 / 3) B^{-1}\left(1+B+B^{2}\right) z_{t},
$$

and a triangular, centered three-period moving average (that is, a moving average with the center observation double-weighted), denoted as TRI(3) $z_{t}$, is defined by the equation ${ }^{17}$

$$
=(1 / 4) B^{-1}\left(1+2 B+B^{2}\right) z_{t} .
$$

Denoting the growth rate of the series as $(1-B) z_{t}$, an MA(3) filter for the growth rate is defined by the equation

$$
=(1 / 3) B^{-1}\left(1+B+B^{2}\right)(1-B) z_{t}
$$

and a TRI(3) filter for the growth rate by the equation

$$
=(1 / 4) B^{-1}\left(1+2 B+B^{2}\right)(1-B) z_{t} .
$$

To assess the smoothing effect of these filters, original and filtered data for TR and IP are shown in Figures 3 and 4, respectively. Over the entire interval between 1913 and 1931, the average annual growth rates and standard deviations of data filtered by MA(3) and TRI(3) differ little. Their cyclical behavior does differ, however. Perhaps not a surprise in annual data, the TRI(3) filter, with its higher weight on the center observation, better preserves cyclical patterns (turning points) than the MA(3) filter. The failure of MA(3)-filtered TR and IP data to accurately reflect the 1919-22 downturn, for example, is a concern. In our judgement, the MA(3) and TRI(3) filters approximately are equivalent with respect to criterion $\mathrm{C}$, that is, reducing volatility of the series, but the TRI(3) filter, equation 2', preserves somewhat better the cyclical patterns in the data relative to the MA(3) filter, equation 1'. Below, we use the TRI(3) filter for all calculations.

- Between 1914 and 1922, we measure annual real GDP growth by a TRI(3)-filtered growth rate of TR. Individual, published observations of NNP are available for the years 1910 and 1924 (see Table 1); observations on TR also are available for these dates. Between these two years,

\footnotetext{
${ }^{16}$ See for example David (1995), chart 2, p. 118.

${ }^{17}$ This filter also is a lagged one-period, double moving-average filter of order MA( $2 \times 2)$.
} 


\section{Figure 3}

Filtered and Unfiltered Railroad Volume, 1913-30
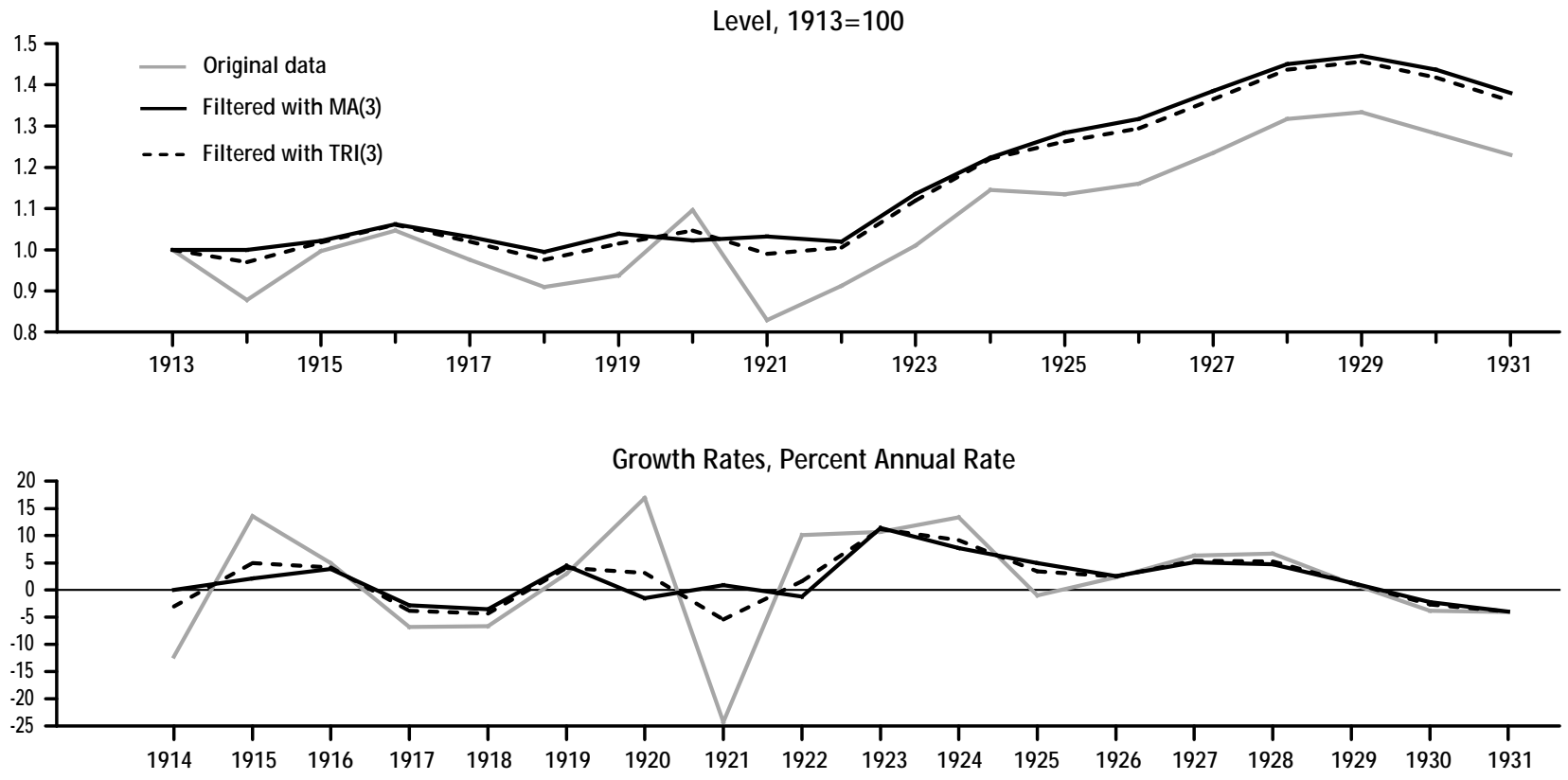

\section{Figure 4}

Filtered and Unfiltered Industrial Production, 1914-31
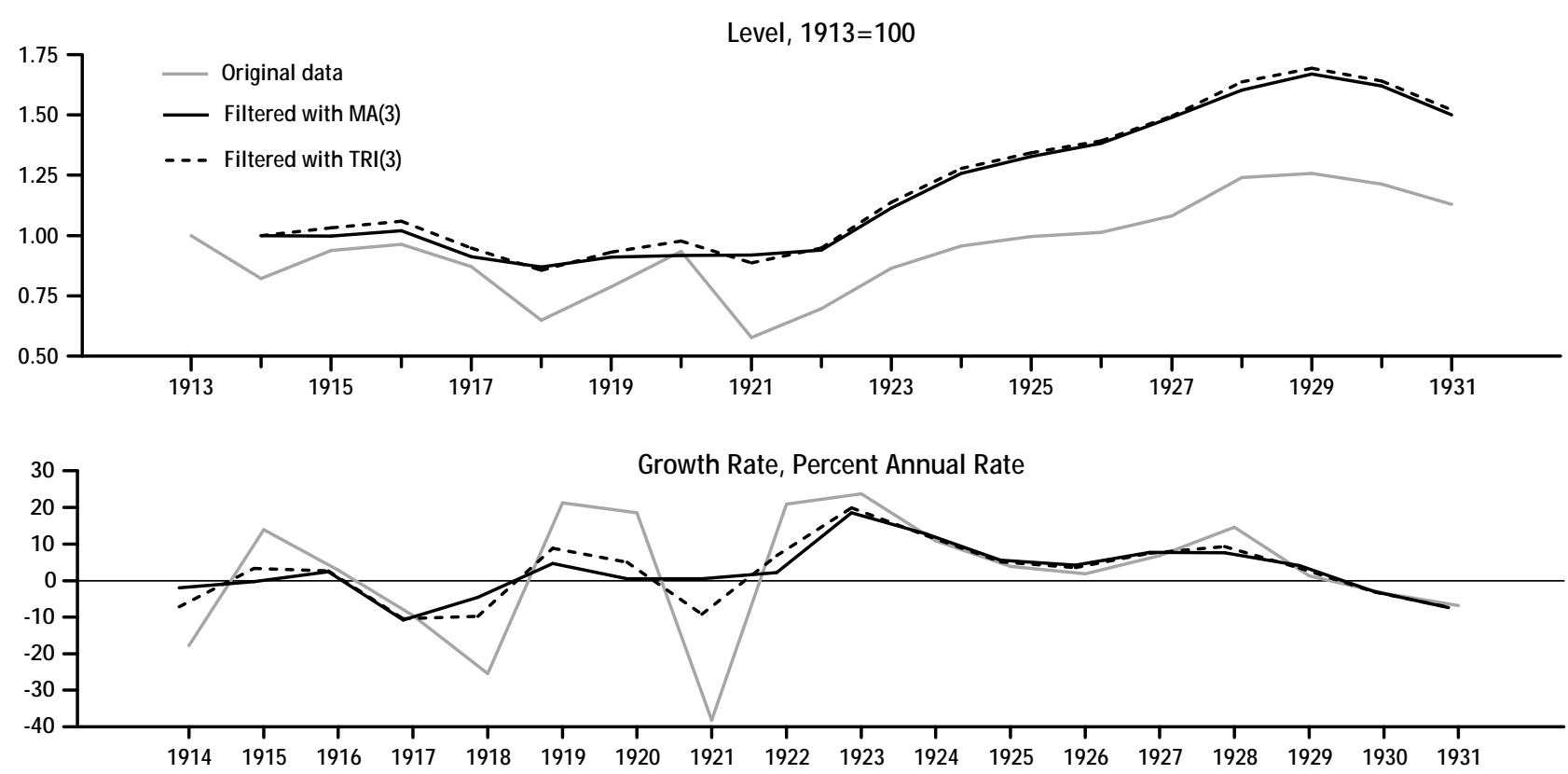


\section{Table 3}

\section{Comparison of Swiss Real Economic Indicators, Selected Periods}

TRI(3) Moving Averages of Annual Growth Rates

Mixed Series

\begin{tabular}{cccc}
\hline Industrial & Railroad & Chained Series & \\
Production & Transport & of Railroad Transport & $\bullet$ 1910- 13: Published GDP \\
& Volume & Volume and Industrial & $\bullet$ 1914- 29: TR+IP, TRI(3) Filter \\
& & Production & $\bullet 1930-40:$ Published NNP \\
\hline
\end{tabular}

A. Growth Rates (average annual growth rate between years indicated, percent)

$\begin{array}{lcccc}1910-1924 & - & 2.1 & 2.0 & 1.6 \\ 1915-1924 & 2.4 & 2.0 & 2.0 & 2.0 \\ 1924-1929 & 5.8 & 3.6 & 5.8 & 5.8 \\ 1915-1930 & 3.1 & 2.2 & 2.9 & 3.1 \\ 1930-1940 & 0.6 & - & 0.6 & 0.1\end{array}$

B. Standard Deviation of Annual Growth Rate

$\begin{array}{lcccc}1910-1924 & - & 5.2 & 5.1 & 4.9 \\ 1915-1924 & 10.7 & 5.9 & 5.7 & 5.7 \\ 1924-1929 & 2.6 & 1.8 & 2.6 & 2.6 \\ 1915-1930 & 8.5 & 4.8 & 5.2 & 4.9 \\ 1930-1940 & 5.6 & - & 5.6 & 3.0\end{array}$

Notes:

Column 1: Swiss industrial production index 1913-45, from David (1995).

Column 2: Railroad transportation volume, 1910-31, from Historical Statistics of Switzerland (1996).

Column 3: For 1913-22, TRI(3)-filtered growth rate of railroad transportation volume. For 1925-40, TRI(3)-filtered growth rate of industrial production. For 1923 and 1924, a TRI(3)-filtered mixture of the growth rates of railroad volume and industrial production (see text).

Column 4: For 1910-13 GDP from Historical Statistics of Switzerland (1996). For 1914-29, the same as column 3. For 1930-40, the annual growth rates of deflated NNP (published nominal NNP deflated by the CPI).

the compound annual growth rate of TR is similar to that of deflated NNP (the first row of Table 2). ${ }^{18}$

- Between 1925 and 1929, we measure real GDP growth by a TRI(3)-filtered growth rate of IP, rather than TR. Beginning in the mid-1920s, railroad transportation increasingly was replaced by private trucks and automobiles. As a result, the volume of railroad transportation became less representative of overall economic activity. Between 1924 and 1929, for example, IP displays an average annual growth rate of 5.6 percent, but the growth rate of TR, 3.1 percent, is well below the growth rate of (deflated) NNP, 5 percent (Table 2). ${ }^{19}$
- For the years 1923 and 1924, we measure real GDP growth by a TRI(3)-filtered mixture of the growth rates of TR and IP. For 1923, we use the growth rate of TR for 1922 and 1923, and IP for 1924. For 1924, we use the growth rate of TR for 1923, and IP for 1924 and 1925. In our judgement, these blended averages providea smooth transition between the earlier (1914-22) and later (192529) periods.

\footnotetext{
${ }^{18}$ In our judgement, growth of tourism, TO, varies so much year-to-year that it is not acceptable as an indicator of real economic growth.

${ }^{19}$ Estimates of the level of nominal NNP are available for 1924 and 1929, but not the years in between.
} 
Table 4

Comparison of Industrial Production and Real GNP/GDP, Switzerland and United States, Selected Periods

\begin{tabular}{|c|c|c|c|c|c|c|}
\hline \multicolumn{4}{|c|}{ Switzerland } & \multicolumn{3}{|c|}{ United States } \\
\hline Period & $\begin{array}{l}\text { Industrial } \\
\text { Production }\end{array}$ & $\begin{array}{l}\text { Industrial } \\
\text { Production, } \\
\text { TRI(3) } \\
\text { Filtered }\end{array}$ & $\begin{array}{l}\text { Real GDP, } \\
\text { Estimated in } \\
\text { This Article }\end{array}$ & $\begin{array}{l}\text { Industrial } \\
\text { Production }\end{array}$ & $\begin{array}{c}\text { Industrial } \\
\text { Production, } \\
\text { TRI(3) } \\
\text { Filtered }\end{array}$ & GNP \\
\hline \multicolumn{7}{|c|}{ A. Growth rates (compound annual rate between years indicated, percent) } \\
\hline 1915-1930 & 1.7 & 3.1 & 3.1 & 3.3 & 4.2 & 2.7 \\
\hline 1915-1920 & -0.1 & -1.1 & 0.6 & 5.2 & 4.3 & 2.4 \\
\hline 1920-1930 & 2.7 & 5.3 & 4.4 & 2.4 & 4.1 & 2.8 \\
\hline 1920-1940 & 1.3 & 2.9 & 2.2 & 3.0 & 4.3 & 2.3 \\
\hline 1930-1940 & 0.1 & 0.6 & 0.1 & 3.3 & 4.7 & 1.8 \\
\hline \multicolumn{7}{|c|}{ B. Standard Deviation of Annual Growth Rates } \\
\hline 1915-1930 & 17.4 & 8.5 & 4.9 & 13.7 & 6.6 & 7.7 \\
\hline 1915-1920 & 19.6 & 8.8 & 4.3 & 7.8 & 8.0 & 7.3 \\
\hline 1920-1930 & 17.3 & 8.0 & 4.9 & 16.2 & 6.2 & 8.2 \\
\hline 1920-1940 & 15.5 & 7.2 & 4.6 & 16.1 & 10.0 & 8.3 \\
\hline 1930-1940 & 14.2 & 5.6 & 3.0 & 18.8 & 13.2 & 8.8 \\
\hline
\end{tabular}

\section{Figure 5}

\section{Combined Railroad Transport + Industrial Production Series, 1913-30}

Growth Rate, Percent Annual Rate

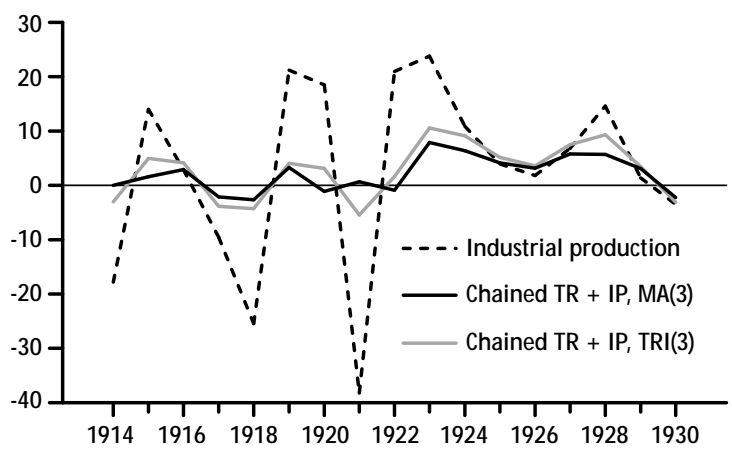

Below, we use the expression TR + IP to refer to our estimates of real GDP growth between 1914 and 1929. For comparison, Figure 5 displays annual growth rates from 1913 to 1930 for IP and two variants of $T R+I P$, one built with the MA(3) filter and one with the TRI(3) filter.

A comparison of Tables 2 and 3 shows that, between 1915 and 1930, the growth rate of TR + IP, 2.9 percent, is similar to that of real NNI, 2.8 percent; between 1915 and 1924, the growth rate of TR+ IP, 2.0 percent, is the same as that of deflated NNI, 1.9 percent; and between 1924 and 1929, the growth rate of TR + IP, 5.8 percent, is somewhat larger than the growth rate of deflated NNI, 5.1 percent.

\section{0-47}

Between 1930 and 1947, we measure the annual growth rate of real GDP by the annual growth rate of 


\section{Figure 6}

\section{Net National Product and Industrial Production}

Annual Data, 1929-45
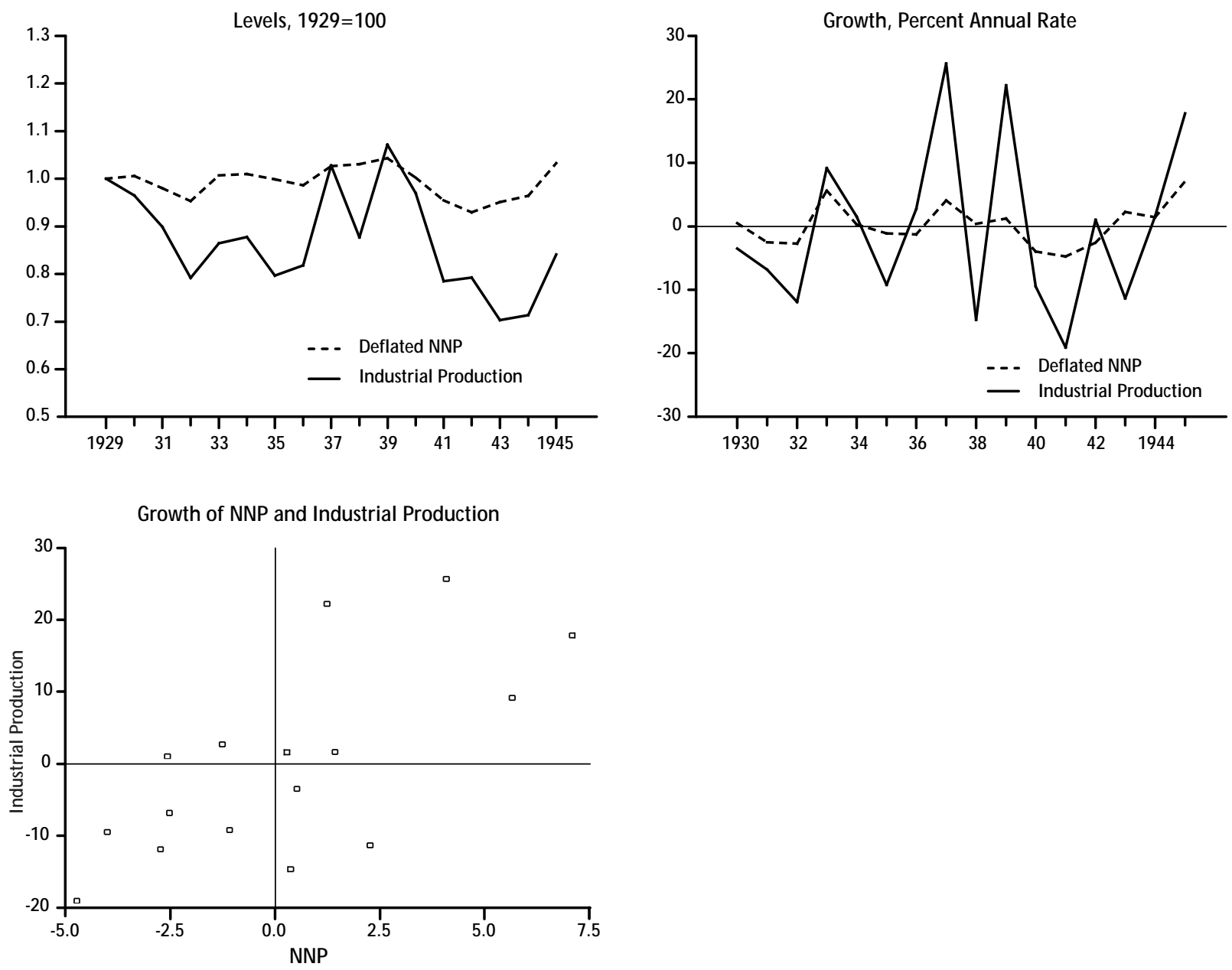

real (deflated) NNP.20 On two important measuresvolatility and cyclical behavior-NNP seems reasonable. The cyclical behaviors of NNP and IP are similar during the 1930s and 1940s, suggesting that the published NNP data accurately indicate cyclical turning points (see Figure 6). Yet, because NNP is a broader measure of the economy, it is much less volatile than IP. In fact, the growth rates of NNP and IP display only a weak positive correlation. Recall that by measuring the growth rates of GDP by the growth rates of NNP we are assuming explicitly that the ratio of depreciation plus net foreign income to GDP is constant. Above, we found this to be consistent with post-World War II Swiss data.
The statistical properties of our final series are summarized in the fourth column of Table 3 for five time intervals. In general, the average annual growth rates of industrial production and our GDP measure are similar (upper panel of Table 3). ${ }^{21}$ At the same time, the volatility of our GDP measure, in terms of standard deviations, is much lower than that of industrial production (the lower panel of Table 3). We find both results encouraging.

\footnotetext{
${ }^{20}$ Note that the growth rate of NNP is not smoothed by moving averages.

${ }^{21}$ Recall that industrial production enters the GDP estimates by itself only between 1925 and 1929, and enters in combination with railroad transport volume during 1923 and 1924.
} 
Figure 7

\section{Swiss NNP and IP Using TRI(3) Filter}
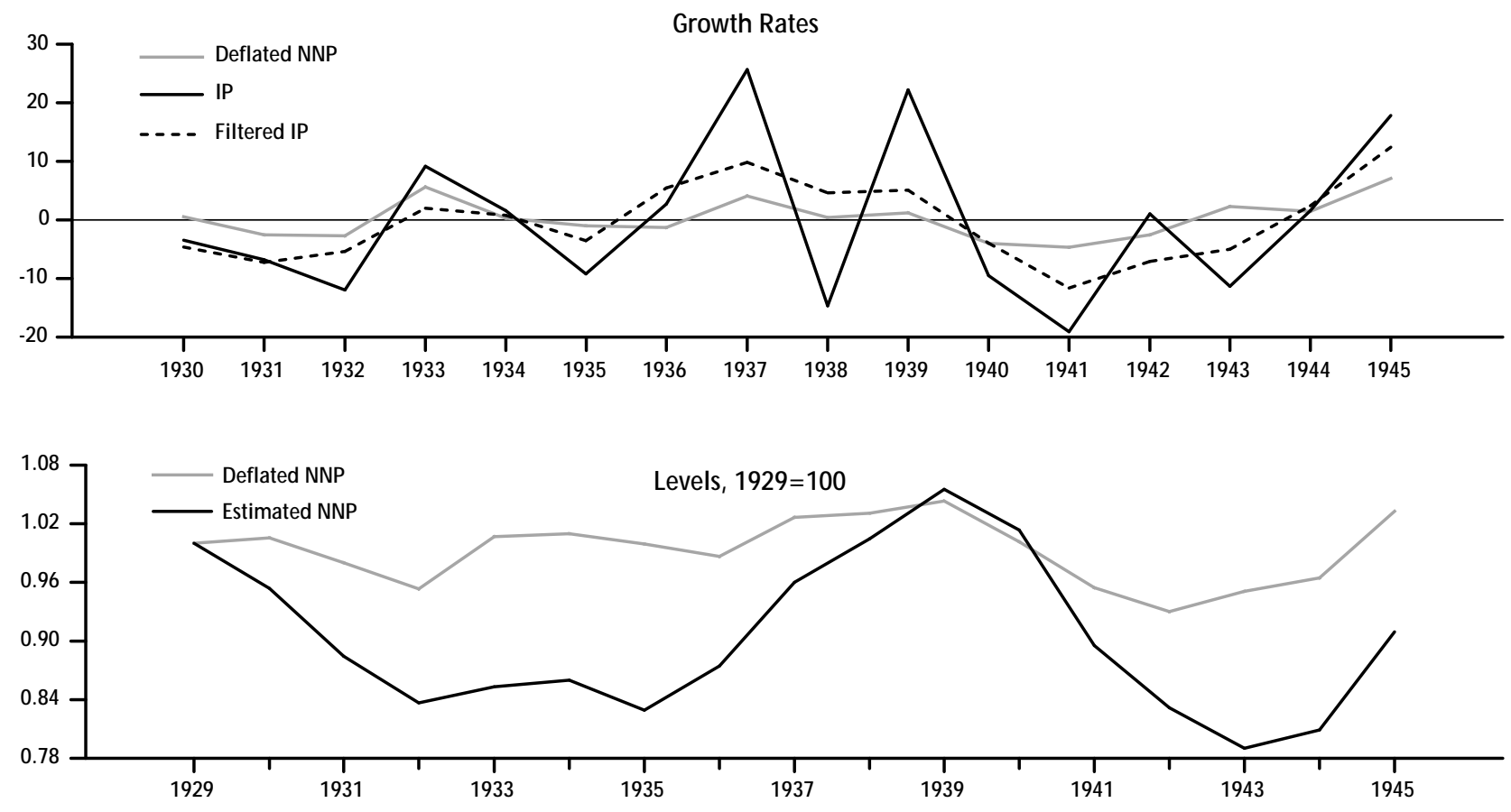

\section{THE EFFECTS OF FILTERING: U.S. GNP AND SWSS NNP VS. INDUSTRIAL PRODUCTION}

To examine further the properties of the TRI(3) moving average filter, we compare filtered U.S. industrial production to U.S. real GNP between 1909 and 1941, and filtered Swiss industrial production to deflated Swiss NNP between 1929 and 1945. ${ }^{22}$ Statistics on the U.S. and Swiss data are shown in Table 4 for selected years. ${ }^{23}$ The volatility of U.S. and Swiss industrial production is similar, and both are far more volatile than GNP or NNP.

The results for Switzerland between 1929 and 1945 are shown in Figure 7. The upper panel displays growth rates of NNP, IP, and IP after smoothing by the TRI(3) filter. ${ }^{24}$ The lower panel displays the level of NNP, normalized to 100 in 1929, and an implied NNP obtained by accumulating the TRI(3)-filtered IP growth rates. During the initial years, the TRI(3)filtered IP series grows more slowly than NNP, and the implied level of NNP falls well below the actual. Later, between 1935 and 1939, the filtered IP series grows more rapidly, and the implied level of NNP increases well above the actual, before reversing between 1940 and $1943 .{ }^{25}$ The situation is improved, of course, when the implied 1945 level is constrained to match the actual level. Overall, it is evident from the figure that a filter designed to smooth fluctuations in a data series, such as TRI(3), does not perform well during periods when there is a significant shift in the level of the series, that is, when the growth rate of IP is persistently above or below that of NNP. Here, the

\footnotetext{
${ }^{22}$ The Swiss IP data are from David (1995). The Swiss NNP data, from Historical Statistics of Switzerland (1996), are published in three segments. We have spliced the data at overlapping years (using a simple ratio of the levels) to create a single time series.

${ }^{23}$ Following Romer (1999), we use the standard deviation as a volatility measure.

${ }^{24}$ Because the sample periods are short, we calculate TRI(3)-filtered observations for the endpoints in 1909, 1915, 1930, and 1940. For each period, the missing leading or lagged observation is omitted and the TRI(3)-filtered observation is calculated from the available growth rates. Between 1909 and 1930, for example, the TRI(3)-filtered value for 1909 is the average of the growth rates for 1909 (weighted twice) and 1910; for 1930, it is the average of the growth rates for 1929 and 1930 (weighted twice). The results are changed little if we omit these observations.

${ }^{25}$ We also examined MA(5) and TRI(5) filters. Average growth rates were not closer to the NNP growth rates and the standard deviations were not smaller. The turning points moved away from the observed turning points.
} 


\section{Figure 8}

\section{U.S. GNP and IP (Miron/Romer) Using TRI(3) Filter, 1909-31}
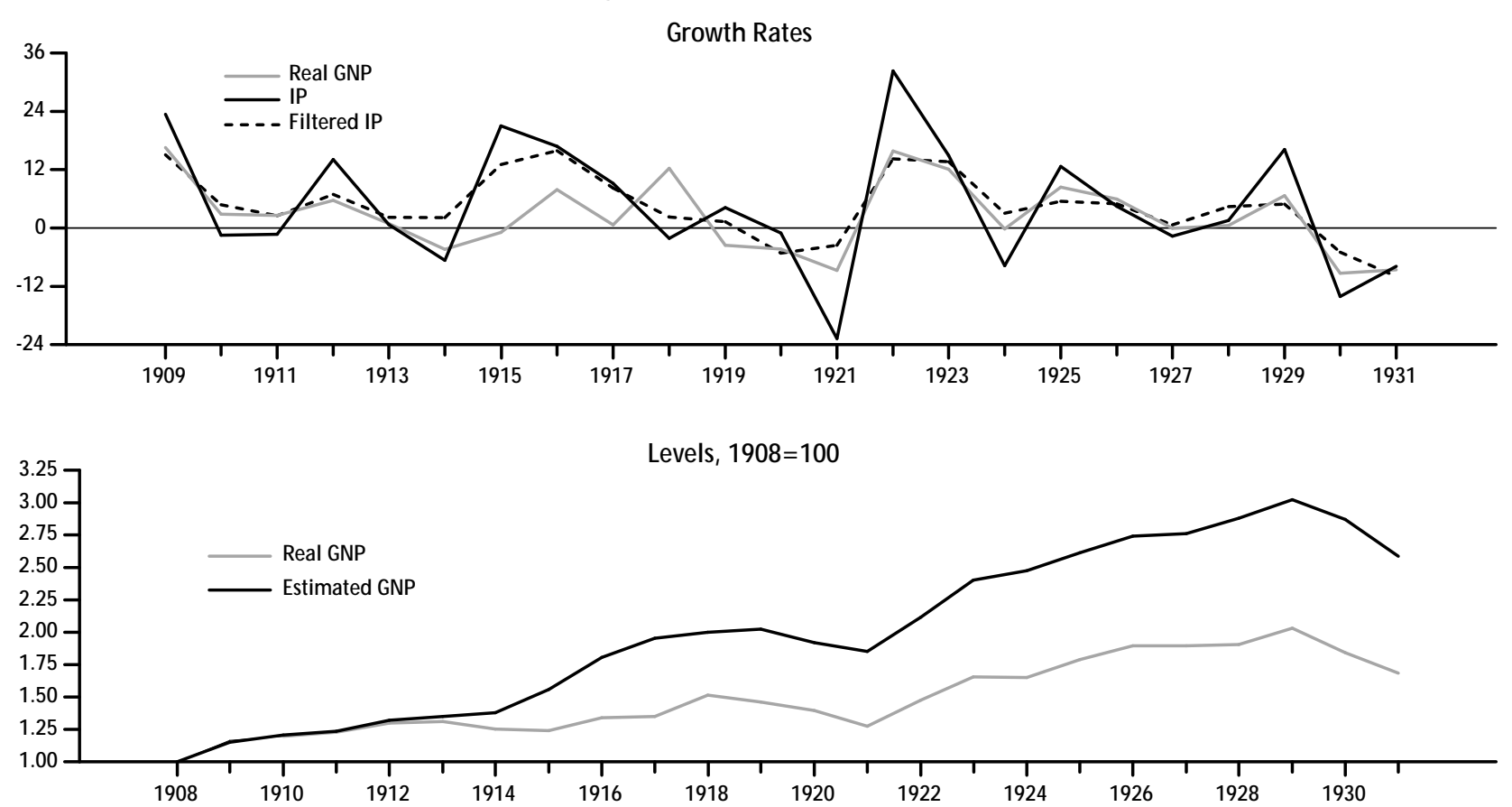

failure of TRI(3)-filtered IP to track Swiss NNP may be due, in part, to the strong effect of World War II in Europe on Switzerland, and perhaps does not indicate a general weakness of the smoothing method.

The results for the United States are shown in Figures 8, 9, and 10 for three periods: between 1909-30, 1915-30, and 1915-40. Figures 8 and 9 use annual averages of the IP data from Miron and Romer (1990), available between 1908 and 1931, while Figure 10 uses IP data from Mitchell (1998), available between 1914 and 1941. All three figures use historical real GDP (in 1982 prices) from Mitchell (1998), available between 1908 and 1950. The TRI(3) filter smoothes the growth rate of IP so that it is similar to the growth rate of GNP (Table 4). The volatility of the growth rates of the filtered IP data, measured as the standard deviation of annual percentage changes, is similar to that of the published GNP data. The correspondence of the growth rates is better between 1920 and 1930, for example, than between 1915 and 1920. In part, this may be due to the high volatility of both series between 1915 and 1920, and to the unusual behavior of IP relative to GNP between 1918 and 1920, as noted by Romer (1989). The figures, however, make it clear that the filter has difficulty when the growth rate of IP is persistently above or below that of GNP, such as between 1915-17, 1933-36, and 1939-41. Constraining the endpoints of the implied GNP series to match the endpoints of the actual GNP series produces a superior estimate in all three figures.

We conclude that the TRI(3) moving average filter works well as a smoothing device to reduce the volatility of indicators. It does not cope well with periods where in the growth rate of an indicator is persistently larger or smaller than the growth rate of the actual broad economic aggregate, however, such as Swiss deflated NNP or U.S. real GDP. In these cases, the estimates may be considerably improved by constraining the endpoints of the filtered series to match the actual values of NNP or GNP. Note that this problem only affects volatility: Cyclical turning points in both U.S. and Swiss data appeared well-preserved by the TRI(3) filter.

\section{ARE OUR ESTIMATES ACCEPTABLE?}

We evaluate our final estimates by asking how closely they satisfy the criteria A, B, and C listed above 


\section{Figure 9}

\section{U.S. GNP and IP (Miron/Romer) Using TRI(3) Filter, 1913-31}
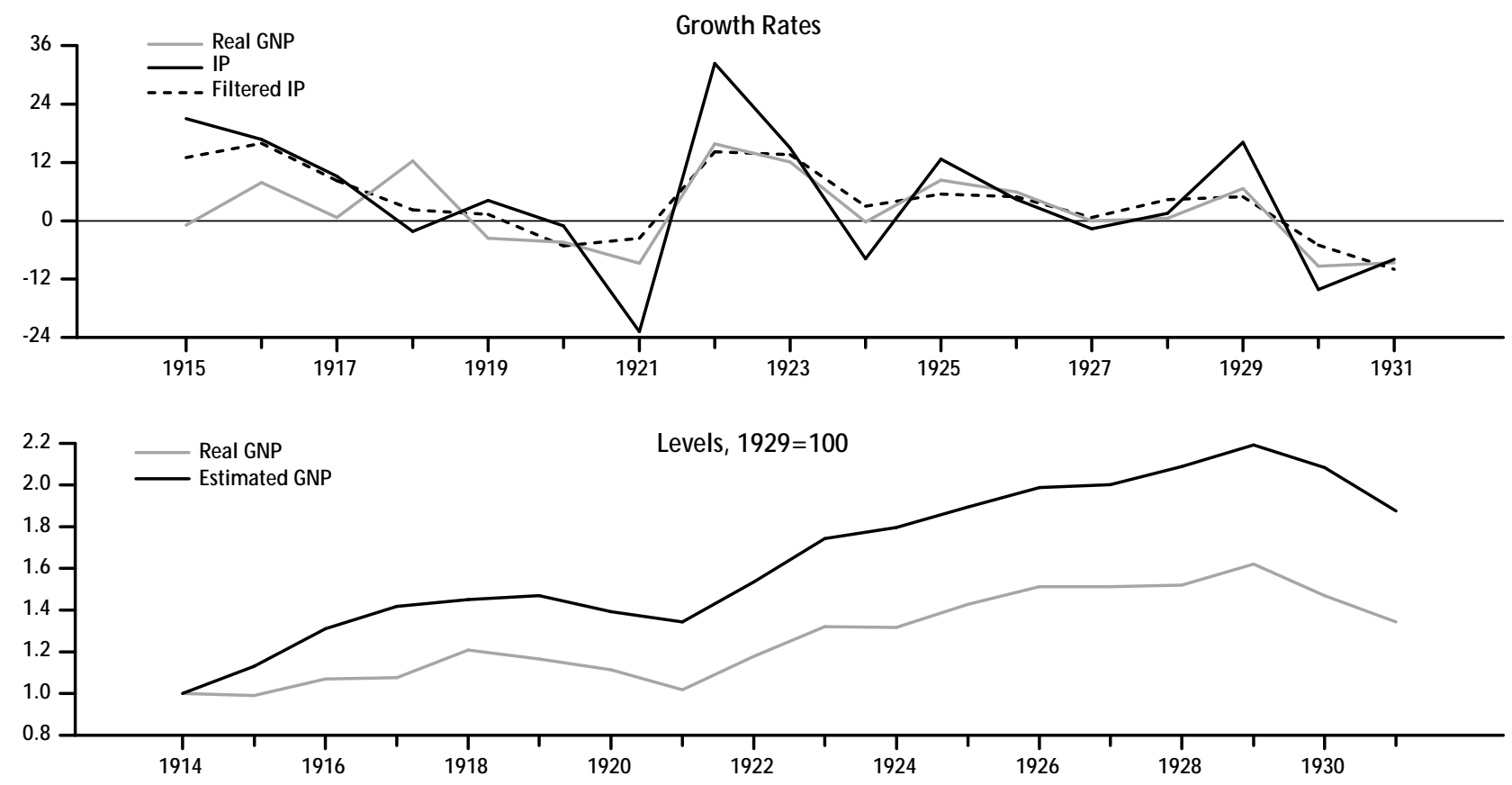

\section{Figure 10}

\section{U.S. GNP and IP (Mitchell) Using TRI(3) Filter, 1914-41}
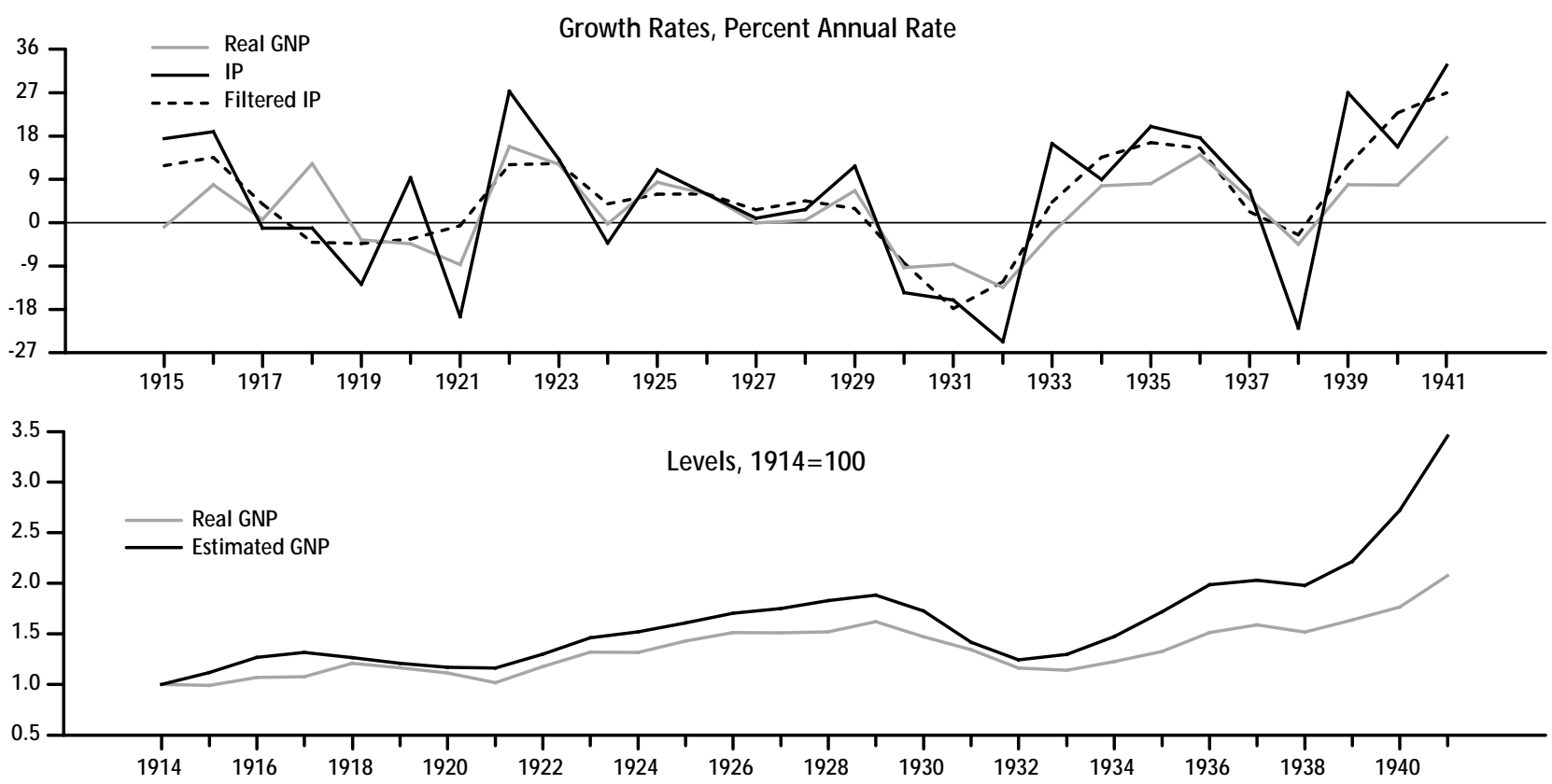


\section{SWISS NATIONAL INCOME AND FOREIGN TRADE}

Swiss citizens, through a long tradition of foreign trade, have accumulated large amounts of capital abroad. The accumulation of foreign capital has been intertwined with the growth of foreign trade since the 16th century. The signing of the "eternal treaty of peace" with France in 1516 marked a watershed in the direction of the Swiss economy (Biucchi, 1979). Before the treaty, the Swiss cantons-geographically surrounded by France to the west, the Hapbsburg empire (today's Austria) to the east, the German principalities to the north, and today's Italy to the south-often had been involved in battles and wars. The treaty required the Swiss Confederation, a group of cantons (states), to retire from "war activities." (The battle of Marignano in 1515 was the last time that Swiss soldiers fought outside the Swiss border against soldiers from another country.) Further, before the treaty, the male population not employed in agriculture, crafts, or trade often worked abroad as mercenaries for foreign nobles. The treaty regulated and reduced the number of Swiss serving in such employment.

The treaty of 1516 also opened the European market to Swiss trade. In exchange for restrictions on the "export" of Swiss mercenaries, the cantons negotiated trade concessions and customs privileges. As a result, in several cantons new enterprises were quickly founded to produce mainly exports. Not coincidentally, these industries also provided employment for young people who formerly had left Switzerland as mercenaries. The new enterprises produced textiles such as cotton and silk and, starting with the 17th century, watches. Expansion of these export-oriented industries dominated future Swiss economic growth, while output of older, traditional craft industries increased slowly (Bernegger, 1990).
For 1798 , it is estimated that about 62.5 percent of the active population worked in agriculture, 25 percent in the production of goods, and 12.5 percent in services (Bergier, 1983). By 1900, agriculture employed only 31 percent, goods production 45 percent, and services 24 percent. Throughout the 18th and 19th centuries, industrialization and international trade grew hand-in-hand: Switzerland's small amounts of mineral resources and raw materials forced its industries to specialize in the production of high-quality, high value-added goods.

Swiss exports, of course, were not limited to goods and services. In the 16th century, the Swiss Confederation was one of the first continentalEuropean countries to export capital, mainly to France and Germany (Landmann, 1916). Initially, the capital came from two sources: savings accumulated by mercenaries and the wealth of well-to-do émigrés from elsewhere in Europe (including the Huguenots). During the 17th century, this wealth was increased by Swiss merchant traders. (Merchant traders also were becoming wealthy in other countries: Recall that the Bank of England was founded in 1694 by wine merchants.) Today, the Swiss tradition of accumulating and exporting capital continues.

The relative roles of foreign factor income in the Swiss and U.S. economies are compared in the table below. Recall that the difference between gross domestic and gross national product equals the net receipts by Swiss residents of factor income from nonresidents. In 1997, these receipts were more than 4-1/2 percent of Swiss net national income, while they were negative for the United States. Although U.S. net receipts also were negative in 1997, receipts were positive in 1995 and 1996: But even during those years, net receipts were less than one-half of 1 percent of national income.

continued on next page

\section{Volatility}

Measured by the standard deviation of growth rates, the moving average filter TRI(3) produces filtered series (as proxies for GDP growth rates from 1914-29) with about one-half the volatility of the initial series, TR or IP; compare the lower panels of Tables 2 and 3 and Figures 3 and 4 . Yet, it does not seem to smooth the data excessively. For the years between 1930 and 1948, we have argued that the growth rate of real (deflated) NNP is a good proxy for the growth of real GDP. It seems unlikely that the differences between GDP and NNP_-depreciation of capital and net factor income received from abroadaffect the relative volatility of their annual growth rates. We conclude that our estimates are acceptable with respect to criterion $\mathrm{C}$. 


$\begin{array}{lc}\begin{array}{l}\text { continued from } \\ \text { previous page }\end{array} & \text { Gross National Product and Income, } 1997 \\ & \text { Switzerland } \\ \text { (Billions of } \\ \text { Swiss Francs) }\end{array}$

Gross Domestic Product

+ Receipts of factor income from, less payments to, the rest of the world

$=$ Gross National Income

- Consumption of Fixed Capital (Depreciation)

$=$ Net National Product

+ Adjustments for: indirect taxes; payments not received by producers for product shipped; subsidies to, minus surpluses of, government enterprises; and statistical discrepancy
371.6
21.8
393.4
58.8
334.6
$-18.1$
$8,511.0$
$-20.4$
$8,490.6$
908.0
$7,582.6$
$-587.8$

United States

(Billions of

U.S. Dollars)

$=$ Net National Income

316.5

$6,994.7$

\section{Business Cycles}

Our proxy series seems to provide a reasonably accurate picture of the Swiss business cycle. The Swiss economy expanded from 1909 through the outbreak of World War I in Europe ${ }^{26}$ During the war, the economy stagnated. Exports of consumption goods slumped as Switzerland's trading partners focused on arms production and limited imports. In Switzerland, economic conditions were dominated by huge increases in the prices of imported goods and the overall CPI. Immediately after the war, economic growth increased sharply with a rebound of foreign demand for consumption and luxury goods. In 1920, the Swiss franc appreciated sharply against the currencies of Switzerland's neighbors, which were the most important export destinations. Although exports fell rapidly, domestic demand remained strong until 1921. Then, in line with the world economy, Switzerland fell into a sharp recession. The depth of the recession, however, was damped by domestic demand. Exchangerate developments and a general fall in consumer prices sharply increased consumer purchasing power, despite a decrease in nominal wages and salaries. Recovery was aided by a Swiss government program to stimulate growth and reduce unemployment, the so-called "electrification program." Between 1923 and 1930, the Swiss economy expanded in line with the world economy.

All the available indicator variables-industrial production, railroad transportation volume, the number of arrivals in hotels, and deflated net national productfit this description of the Swiss business cycle well. The common co-movements in these indicators likely arose because Switzerland is a small open economy. As such, increases and decreases in economic activity are correlated strongly with foreign demand. During the years 1915 to 1918, 1921, and 1930 to 1935, for example, the foreign-demand component of industrial production declined much more than the corresponding domestic components.

\section{Trends}

The final step in our estimation is to accumulate, from 1913 to 1948, the implied annual increases in real GDP. Our starting point is the Swiss National Fund project's estimate of nominal GDP for 1913 (SFr 4.009 billion), deflated by the Swiss CPI for 1913 (12.61, $1990=100$ ), equal to SFr 31.8 billion. Estimated annual levels of real GDP are shown in Table 6, column 5; for reference, columns 1 through 4 show our estimates of the annual growth rates.

The first row of Table 5 compares our estimated level of real GDP for 1948, SFr 65.2 billion, to two benchmark estimates published by the Swiss Federal Bureau of Statistics. The first is the published level of nominal GDP during 1948 (SFr 19.8 billion), deflated (by us) using the Swiss CPI for 1948 (28.2, $1990=100$ ), equal to SFr 70.5 billion. The second is the Federal Bureau's published level of real GDP in 1990 prices, SFr 89.0 billion. Our estimate of SFr 65.2 billion would need to be increased by 8.1 percent to equal the first published value, or equiva-

\footnotetext{
${ }^{26}$ This paragraph is based on Böhi (1964, pp. 83-86) and Siegenthaler (1987, pp. 493-500).
} 
Table 5

Comparison of Estimated and Published Swiss Real GDP for 1948 (Billions of Swiss Francs, at 1990 Prices)

\begin{tabular}{|c|c|c|c|}
\hline & $\begin{array}{l}\text { Estimate in } \\
\text { This article }\end{array}$ & $\begin{array}{l}\text { Published Nominal GDP, } \\
\text { Deflated by CPI }\end{array}$ & Published Real GD \\
\hline & SFr 65.2 & SFr 70.5 & SFr 89.0 \\
\hline $\begin{array}{l}\text { Discrepancy between level of real GDP } \\
\text { estimated in this article and published values, } \\
\text { in percent of this article's estimate }\end{array}$ & - & $8.1 \%$ & $36.5 \%$ \\
\hline $\begin{array}{l}\text { Compound average annual growth rates of real GDP, } \\
\text { 1913-48 }\end{array}$ & 2.1 & 2.3 & 3.0 \\
\hline $\begin{array}{l}\text { Difference between annual growth rate of GDP } \\
\text { estimated in this article (column 1) and published } \\
\text { nominal GDP deflated by the CPI, 1913-48 }\end{array}$ & - & -0.2 & - \\
\hline $\begin{array}{l}\text { Difference between annual growth rate of GDP } \\
\text { estimated in this article (column 1) and published } \\
\text { real GDP, 1913-48 }\end{array}$ & - & - & -0.9 \\
\hline
\end{tabular}

\section{Memo:}

CPI Price Index for 1913, $1990=100$

CPI Price Index for 1948, $1990=100$

GDP implicit price deflator for $1948,1990=100 \quad 22.4$

lently its average annual growth rate between 1914 and 1948 would need to be increased by 0.2 percentage points, from 2.1 to 2.3 percent. Relative to the second, our estimate would need to be increased by 36.5 percent to equal the published value, equivalent to an increase in its average annual growth rate of approximately 0.9 percentage points, to 3.0 percent.

The discrepancies between our estimate and the Federal Bureau's estimates suggest three possi bilities:

- Our procedure might underestimate real GDP growth between 1913 and 1948. To test this, we compared our estimates to published measures of the growth of U.S. real GNP between 1915 and 1938 (this period is chosen so as to exclude World War II). Between 191521 and 1915-38, our estimates of the growth of Swiss real GDP are very close to the growth of
U.S. real GDP. Moreover, although the volatility of the Swiss and U.S. data differ, the recessions of 1921 and 1932 are clear in both data. We conclude that our estimates of the longer-run growth of Swiss real GDP are unlikely to be significantly misspecified.

- The starting point for our estimate- the Swiss National Fund project's estimated level of nominal GDP during 1913-may be too low. Some support for this view is evident in a comparison of the data shown in Table 1 for the years between 1910 and 1920 . How large a shortfall in 1913 would be necessary to account for the differences in 1948? Table 6, column 6, shows a counterfactual experiment in which we calculate backwards from the Federal Bureau's published estimate for 1948 (SFr 89.0 billion), using the growth rates 
Table 6

Summary of Estimates

\begin{tabular}{|c|c|c|c|c|c|c|}
\hline & \multicolumn{4}{|c|}{$\begin{array}{c}\text { Growth Rate of Swiss Real GDP } \\
\text { (percent annual rate) }\end{array}$} & \multicolumn{2}{|c|}{$\begin{array}{l}\text { Level of Swiss Real GDP } \\
\text { (SFr. Billions, } 1990 \text { prices) }\end{array}$} \\
\hline & \multicolumn{3}{|c|}{$\begin{array}{l}\text { TRI(3) Moving Averages } \\
\text { of Annual Growth Rates }\end{array}$} & \multirow{2}{*}{$\begin{array}{c}\text { Annual } \\
\text { Growth Rates } \\
\text { Deflated Net } \\
\text { National Product } \\
\text { 1930-48 }\end{array}$} & & \\
\hline & $\begin{array}{l}\text { Railroad } \\
\text { Transport } \\
\text { Volume } \\
\text { 1914-22 }\end{array}$ & $\begin{array}{l}\text { Mixed Railroad } \\
\text { Transport and } \\
\text { Industrial } \\
\text { Production } \\
\text { 1923-24 }\end{array}$ & $\begin{array}{l}\text { Industrial } \\
\text { Production } \\
1925-29\end{array}$ & & $\begin{array}{l}\text { Estimate obtained } \\
\text { by starting with } \\
\text { published } 1913 \\
\text { level and } \\
\text { accumulating } \\
\text { growth to } 1948\end{array}$ & $\begin{array}{l}\text { Estimate obtained } \\
\text { by starting with } \\
\text { published } 1948 \\
\text { level and decumulating } \\
\text { growth backward } \\
\text { to } 1913\end{array}$ \\
\hline 1913 & & & & & 31.8 & 43.4 \\
\hline 1914 & -3.04 & & & & 30.8 & 42.1 \\
\hline 1915 & 4.97 & & & & 32.4 & 44.2 \\
\hline 1916 & 4.17 & & & & 33.7 & 46.0 \\
\hline 1917 & -3.84 & & & & 32.4 & 44.3 \\
\hline 1918 & -4.31 & & & & 31.0 & 42.3 \\
\hline 1919 & 4.05 & & & & 32.3 & 44.1 \\
\hline 1920 & 3.12 & & & & 33.3 & 45.4 \\
\hline 1921 & -5.43 & & & & 31.5 & 43.0 \\
\hline 1922 & 1.62 & & & & 32.0 & 43.7 \\
\hline 1923 & & 10.59 & & & 35.4 & 48.3 \\
\hline 1924 & & 9.11 & & & 38.6 & 52.7 \\
\hline 1925 & & & 5.16 & & 40.6 & 55.4 \\
\hline 1926 & & & 3.60 & & 42.0 & 57.4 \\
\hline 1927 & & & 7.50 & & 45.2 & 61.7 \\
\hline 1928 & & & 9.34 & & 49.4 & 67.5 \\
\hline 1929 & & & 3.46 & & 51.1 & 69.8 \\
\hline 1930 & & & & 0.53 & 51.4 & 70.2 \\
\hline 1931 & & & & -2.52 & 50.1 & 68.4 \\
\hline 1932 & & & & -2.73 & 48.7 & 66.5 \\
\hline 1933 & & & & 5.65 & 51.5 & 70.3 \\
\hline 1934 & & & & 0.29 & 51.6 & 70.5 \\
\hline 1935 & & & & -1.08 & 51.1 & 69.7 \\
\hline 1936 & & & & -1.26 & 50.4 & 68.9 \\
\hline 1937 & & & & 4.08 & 52.5 & 71.7 \\
\hline 1938 & & & & 0.37 & 52.7 & 71.9 \\
\hline 1939 & & & & 1.24 & 53.3 & 72.8 \\
\hline 1940 & & & & -3.99 & 51.2 & 69.9 \\
\hline 1941 & & & & -4.72 & 48.8 & 66.6 \\
\hline 1942 & & & & -2.57 & 47.5 & 64.9 \\
\hline 1943 & & & & 2.26 & 48.6 & 66.4 \\
\hline 1944 & & & & 1.43 & 49.3 & 67.3 \\
\hline 1945 & & & & 7.08 & 52.8 & 72.1 \\
\hline 1946 & & & & 13.87 & 60.1 & 82.1 \\
\hline 1947 & & & & 7.77 & 64.8 & 88.5 \\
\hline 1948 & & & & 0.62 & 65.2 & 89.0 \\
\hline
\end{tabular}


shown in columns 1-4. The difference for 1913 in 1990 prices is (SFr $43.4-\mathrm{SFr}$ 31.8)=

SFr 11.6 billion, or SFr 1.46 billion in 1913 prices, equal to 36 percent of the National Fund project's 1913 estimated level. Even if the project's estimate is low, it seems unlikely that it is that low. In a second experiment, not shown in the table, we repeat the above experiment beginning with the Federal Bureau's published estimate for nominal GDP deflated by the CPI, equal to SFr 70.5 billion. The difference for 1913 in 1990 prices is (SFr 34.4 - SFr 31.8) = SFr 2.6 billion, or approximately SFr 320 million in 1913 prices, 8.2 percent of the project's estimated 1913 level. This difference may be within the margin of error of the project's estimate.

\section{- Some of the discrepancy may be due to} differences between the aggregate Swiss CPI and the price indexes for individual items used by the Federal Bureau to construct real GDP. The results of the previous paragraph support this possibility. In our estimation, we use the CPI to deflate both the National Fund project's estimate of nominal GDP for 1913 and published values of nominal NNP between 1930 and 1947. The CPI is a fixed-weight Laspeyres index, and the biases in such indexes due to the use of fixed weights are well known; see Balaster (1992), Boskin et al. (1996), Hess et al. (1988). A more appropriate variable-weight index, such as an implicit deflator or chained price index for GDP, is not available. Weights in the Swiss CPI do change when it is revised, but there were only two revisions between 1900 and 1950: in 1913 and 1938. In particular, the relative prices of various consumer goods during 1990 likely are not representative of relative prices in 1913, a point emphasized by Balke and Gordon (1989) for U.S. data. Hence, the level of the CPI for 1913 could be too high, relative to 1948, and the deflated level of GDP for 1913 too low. Unfortunately, we have been unable to find a way to measure the size of such a bias.

Despite these possible shortfalls, our measure of real GDP seems to follow trends reasonably well during shorter intervals.

1910-1924: As noted above, careful estimates of nominal GDP have been published for 1910, and nominal NNP for 1910 and 1924. Although each of these estimates is based on detailed data, some uncertainty must remain regarding how close the estimates are to the true unobserved values. Because we suspect that a similar degree of uncertainty likely is present in the estimates for many other years, we evaluate the performance of our estimates by asking whether the path of our annual values falls within a heuristic, but reasonable, confidence band. For the years 1910 and 1924, respectively, let us assume that the estimates of Zwingli and Ducret (1964) and Wyler (1927 and 1928) are at the upper bound of a range of likely estimates. Also, let us assume, consistent with the range of published estimates, that the smallest values for these years are 20-percent smaller. Next, let us calculate from these levels two boundary growth paths between 1910 and 1924. Let the lower bound be one that connects the largest estimated level for 1910 to the smallest for 1924, and let the upper bound be the one that connects the smallest for 1910 to the largest for 1924. Under these assumptions, the lower and upper bounds for growth between 1910 and 1924 are, respectively, 0.34 and 1.95 percent. The growth rate implied by our time series of annual GDP values is 1.59 percent, within (the admittedly coarse) bounds.

1924- 1929: Using Wyler's estimates of net national product between 1924 and 1929, the calculated average annual growth rate for the period is 5.01 percent per year. Our estimates suggest a very similar rate of 5.79 percent.

\section{CONCLUSIONS}

This study has developed a new measure of annual real GDP in Switzerland between 1914 and 1947. The estimates are based on three indicator variables: the transportation volume of Swiss railroads, industrial production, and deflated net national product. Comparisons to U.S. data during the same period suggest that the estimated growth rate of real GDP is reasonable. Accumulating the implied annual growth beginning with the Swiss National Fund project's estimate of nominal GDP for 1913 (deflated by the CPI), however, yields a level of GDP during 1948 that is lower than the levels published by the Swiss Federal Bureau of Statistics, although not greatly so. This discrepancy might be due to the published nominal GDP level in the 1913 benchmark being too small, or to the CPI being an inadequate measure of prices-available data do not allow us to test these hypotheses. 


\section{REFERENCES}

Balastèr, Peter. Konsumentenpreisindices, Berner Beiträge zur Nationalökonomie, Band 84, Verlag Paul Haupt, Bern, Stuttgart, Wien, 1992.

Balke, Nathan S., and Robert J. Gordon. "The Estimation of Prewar Gross National Product: Methodology and New Evidence," Journal of Political Economy (February 1989), pp. 38-92.

Bergier, François. Die Wirtschaftsgeschichte der Schweiz, Von den Anfängen bis zur Gegenwart, Benziger Verlag, Zürich, 1983.

Bernegger, Michael. "Die Schweiz und die Weltwirtschaft, Etappen der Integration im 19. und 20. Jahrhundert," in Die Schweiz in der Weltwirtschaft, pp. 429-69, Chronos Verlag, Zürich, 1990.

Biucchi, Basilio M. “Die industrielle Revolution in der Schweiz," in Europäische W irtschaftsgeschichte, volume 4 pp. 42-61, (German edition of The Fontana Economic History of Europe), Gustav Fischer Verlag, Köln and New York, 1979.

Böhi, Hans. "Hauptzüge einer schweizerischen Konjunkturgeschichte," Schweizerische Zeitschrift für Volkswirtschaft und Statistik, pp. 71-131, Stämpfli und Cie, Bern, 1964.

Boskin, Michael J., Ellen R. Dulberger, Robert J. Gordon, Zvi Griliches, and Dale Jorgensen. Toward a More Accurate Measure of the Cost of Living, Final Report to the Senate Finance Committee from the Advisory Commission to Study the Consumer Price Index, 1996.

Bureau of Economic Analysis, U.S. Department of Commerce "GDP: One of the Great Inventions of the 20th Century (with commentary)," Survey of Current Business (January 2000), pp. 6-14.

. "Improved Estimates of the National Income and Product Accounts for 1959-95: Results from the Comprehensive Revision," Survey of Current Business (January/February 1996), pp. 1-31.

David, Thomas. "Un indice de la production industrielle de la Suisse durant l'entre-deux-guerres," Schweizerische Zeitschrift für Geschichte, 1995, vol. 45, no. 1, pp. 109-30.

Die Handels-und Zahlungsbilanz, Volkswirtschaft, Arbeitsrecht und Sozialversicherung der Schweiz, Eidgenössisches Volkswirtschaftsdepartement, 1925, Benziger und Co. AG, Einsiedeln, Schweiz.

Federal Statistical Office of Switzerland (Eidgenössisches Statistisches Amt), "Das schweizerische Volkseinkommen 1924,1929 bis 1938, Beiträge zur schweizerischen Statistik, Heft 9, Bern, 1941.
Geering, T., and R. Hotz. Wirtschaftskunde der Schweiz, Zürich, 1902; Fourth edition, 1910; Fifth edition, 1914. Cited in Studenski, 1958, pp. 466-68.

Hess, Thomas, Erich Spörndli, and Phillipe Thalmann. “Deflationierungsprobleme in der schweizerischen Konjunkturstatistik," KOF ETH, Zürich, 1988.

International Monetary Fund. Balance of Payments Manual (1993).

Jaszi, George "An Economic Accountant's Ledger," Survey of Current Business (July 1971), pp. 183-227.

Kuznets, Simon. National Income and Its Composition, 19191938. National Bureau of Economic Research, 1941.

. . . . . . . . National Product Since 1869. General Series, number 46. National Bureau of Economic Research, 1946.

Landmann, Julius. "Der schweizerische Kapitalexport," Zeitschrift für schweizerische Statistik und Volkswirtschaft, 52. Jahrgang, pp. 389-415, 1916.

Lurati, Francesco. "Skizze der historischen und theoretischen Grundlagen der Volkseinkommensrechnung und der Nationalen Buchhaltung," Mitteilungsblatt für Konjunkturfragen 4/93, Bundesamt für Konjunkturfragen, Switzerland, 1993.

Meade, James E., and Richard Stone National Income and Expenditure, Cambridge University Press, 1944.

Miron, Jeffrey A., and Christina D. Romer. "A New Monthly Index of Industrial Production, 1884-1940," Journal of Economic History (June 1990), pp. 321-37.

Mori, Paul, "Das schweizerische Volkseinkommen," Schweizerische Zeitschrift für Statistik und Volkswirtschaft, Bern, 1928.

Mitchell, B.R. International Historical Statistics: The Americas 1750-1993. Fourth edition, Stockton Press, New York, 1998.

Ritzmann-Blickenstorfer, Heiner, Historical Statistics of Switzerland, Chronos Verlag, Zürich, 1996.

Romer, Christina D. "New Estimates of Prewar Gross National Product and Unemployment," Journal of Economic History (June 1986), pp. 341-52.

"The Prewar Business Cycle Reconsidered: -New Estimates of Gross National Product, 1869-1908," Journal of Political Economy (February 1989), pp. 1-37. . "Changes in Business Cycles: Evidence and Explanations," Journal of Economic Perspectives (Spring 1999), pp. 23-44.

Roncaglia, Alessandro. "William Petty," The New Palgrave Dictionary of Economics, John Eatwell, Murray Milgate, and Peter Newman, eds., Macmillan, 1987, pp. 853-55.

Ruggles, Richard, and Nancy Ruggles. "The Evolution of National Accounts and the National Data Base," Survey of Current Business (July 1971), pp. 152-61. 
Ruoss, Eveline Die Geldpolitik der Schweizerischen Nationalbank 1907-1929, Grundlagen, Ziele und Instrumente, Dissertation der wirtschaftswissenschaftlichen Fakultät der Universität Zürich, 1992.

Samuelson, Paul A. "The 1984 Nobel Prize in Economics," Science, vol. 227, January 1985, pp. 20-22. Reprinted as chapter 364 in The Collected Scientific Papers of Paul A. Samuelson, volume 5, Kate Crowley, ed., M.I.T. Press, 1986, pp. 841-43.

. “Quesnay's 'Tableau Economique' as a Theorist Would Formulate it Today," in Classical and Marxian Political Economy: Essays in Honor of Ronald L. Meek. Ian Bradley and Michael Howard, eds., St. Martin's Press, 1982. Reprinted as chapter 343 in The Collected Scientific Papers of Paul A. Samuelson, volume 5, Kate Crowley, ed., M.I.T. Press, 1986, pp. 630-63.

.Adam the Immortal," The Pennsylvania Gazette (November 1976), pp. 26-27. Reprinted as chapter 276 in The Collected Scientific Papers of Paul A. Samuelson, volume 4, Hiroaki Nagatani and Kate Crowley, eds., M.I.T. Press, 1977, pp. 862-64.

Schneider, S. “Die Steuerbelastung der Kantone” (1921), cited in Statistisches Jahrbuch der Schweiz 1993, p. 131 and Chart 1, p. 132, Verlag Neue Zürcher Zeitung, Zürich, 1993.

Sheffrin, Steven M. “Have Economic Fluctuations Been Dampened? A Look at Evidence Outside the United States." Journal of Monetary Economics 21(1), January 1988, pp. 73-83.

Siegenthaler, Hansjörg. “Die Schweiz 1914-1984," in Handbuch der europäischen Wirtschafts-und Sozialgeschichte, volume 6, W. Fischer, J.A. Van Houtee, H. Kellenbenz, I. Mieck, F. Vittinghoff, eds., Klett-Cotta, 1987.
Statistisches Jahrbuch der Schweiz 1993, Verlag Neue Zürcher, Zeitung, Zürich, 1993, pp.129-34.

Stone, Richard, and Giovanna Stone. National Income and Expenditure. Bowes and Bowes, London, 1961.

Studenski, Paul. The Income of Nations: Theory, Measurement, and Analysis: Past and Present. New York University Press, 1958.

System of National Accounts 1993, jointly authored and published by the Commission of the European CommunitiesEurostat, International Monetary Fund, Organization for Economic Cooperation and Development, United Nations, and the World Bank, 1993.

Teper, Lazare "A History of the Survey of Current Business," Survey of Current Business (July 1971), pp. 178-82.

Watson, Mark W. "Business-Cycle Durations and Postwar Stabilization of the U.S. Economy," The American Economic Review (March 1994), pp. 24-46.

Wyler, Julius. “Das schweizerische Volkseinkommen im Jahre 1924," Schweizerische Zeitschrift für Statistik, 1927, pp. 359-412.

. "Das schweizerische Volkseinkommen im Jahre 1924," Schweizerische Zeitschrift für Statistik, 1928, pp. 52-3.

. . "Das schweizerische Volkseinkommen," Schweizerische Zeitschrift für Statistik, 1941, pp. 171-86.

Zwingli, Ulrich, and Edgar Ducret. "Das Sozialprodukt als Wertmesser des langfristigen Wirtschaftswachstums. Das schweizerische Sozial produkt 1910 und in früheren Jahren," Schweizerische, Zeitschrift für Volkswirtschaft und Statistik, Stämpfli und Cie, Bern, 1964, pp. 328-68. 


\section{DATA SOURCES}

\section{Swiss Data}

Source: Ritzmann-Blickenstorfer H., Historical Statistics of Switzerland, Chronos Verlag, Zürich, 1996.

Series: • Gross domestic product (GDP) 1910-13

- Nominal net national product (NNP) 1910, 1924, 1929-48

- Guest arrivals at hotels, 1910-48

Source: Swiss Federal Bureau of Statistics

Series: • Nominal net national income(NNI) 1915, 1919, 1924, and 1929

Statistisches Jahrbuch der Schweiz 1993, pp. 129-34

- Nominal gross domestic product (GDP) 1948-95

- Nominal gross national product (GNP) 1948-95

- Nominal depreciation 1948-95

- Consumption price index (CPI) 1910-48

- Deflator for GDP (chain price index), 1948

Source: Ritzmann-Blickenstorfer H., Historical Statistics of Switzerland, Chronos Verlag, Zürich, 1996.

Series: • Transportation volume of Swiss railroads (in thousands of tons), 1910-31

Source: David, T. (1995), Schweizerische Zeitschrift für Geschichte, 1995, vol. 45, no. 1.

Series: • Industrial production index, 1913-45

\section{U.S. Data}

Source: Mitchell B. R., International Historical Statistics, The Americas 1750-1993. Fourth edition, Stockton Press, New York, 1998.

Series: • Gross domestic product (GDP)

- Industrial production index

Source: Miron, Jeffrey A., and Christina D. Romer, "A New Monthly Index of Industrial Production 18841940," Journal of Economic History (June 1990), pp. 321-37.

Series: • Industrial production index 